PONTIFÍCIA UNIVERSIDADE CATÓLICA DO RIO DE JANEIRO

\title{
Mulher empreendedora: Dificuldades e preconceitos
}

\section{Camila Coutinho Loiola}

Trabalho de Conclusão de Curso

Centro de ClênCIAS SOCIAIS - CCS

Departamento de AdMINISTRAÇÃo

Graduação em Administração de Empresas 
Camila Coutinho Loiola

\title{
Mulher empreendedora: Dificuldades e preconceitos
}

\author{
Trabalho de Conclusão de Curso
}

Trabalho de Conclusão de Curso, apresentado ao programa de graduação em Administração da PUC-Rio como requisito parcial para a obtenção do titulo de graduação em Administração.

Orientadora: Patrícia Itala Ferreira

Rio de Janeiro, junho de 2016. 


\section{Agradecimentos}

A minha família que me apoiou durante esse processo de desenvolvimento da minha monografia e também durante toda a faculdade.

Ao meu namorado que também me apoiou e soube respeitar meu espaço e tempo que dediquei à conclusão desse trabalho.

A minha orientadora que com toda sua experiência e capacidade me orientou em todos os momentos dessa etapa.

A faculdade PUC RIO por ter sido grande responsável pelo meu desenvolvimento como aluna e ter me proporcionado um grande aprendizado durante todo o curso de administração e hoje poder concluir meu trabalho de conclusão de curso.

A todos que colaboraram diretamente e indiretamente com esse trabalho.

Muito Obrigada! 


\section{Resumo}

Coutinho Loiola, Camila. Mulher empreendedora: Dificuldades e preconceitos. Rio de Janeiro, 2016. 50p. Trabalho de Conclusão de Curso - Departamento de Administração. Pontifícia Universidade Católica do Rio de Janeiro.

A mulher empreendedora tem buscado seu espaço no mundo dos negócios. Durante o desenvolvimento do seu empreendimento, assim como no mercado de trabalho, sofre dificuldades e preconceitos. O objetivo deste trabalho foi identificar, na opinião dessas mulheres, quais as dificuldades e preconceitos que sofrem quando optam por empreender. Foi realizada uma pesquisa de campo, por meio da realização de entrevistas, com 16 empreendedoras e, a partir dos resultados obtidos, foram feitas conclusões e sugestões para futuros estudos.

Palavras-chave: Mulher empreendedora, dificuldades, preconceitos

\section{Abstract}

Coutinho Loiola, Camila. Entrepreneur woman: Difficulties and prejudices. Rio de Janeiro, 2016. 50p. Trabalho de Conclusão de Curso - Departamento de Administração. Pontifícia Universidade Católica do Rio de Janeiro.

The entrepreneur woman has sought her place on the business world. During the development of her business, as well as in the labor market, suffers difficulties and prejudices. The objective of this study was to identify the entrepreneur women's opinion about what difficulties and prejudices suffer when they choose to undertake. A field survey was conducted through interviews with 16 entrepreneurs and, from the results obtained, were made conclusions and suggestions for future studies.

Key-words: Entrepreneur woman, difficulties, prejudices 


\section{Sumário}

10 tema e o problema de estudo ...............................................................

1.1. Introdução ao tema e o problema do estudo ..................................................

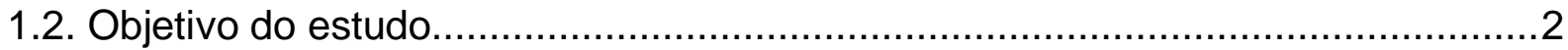

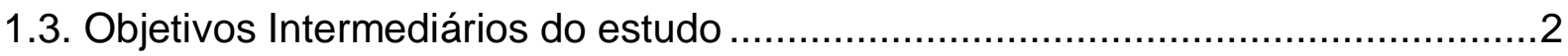

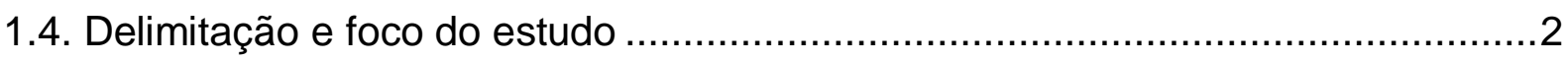

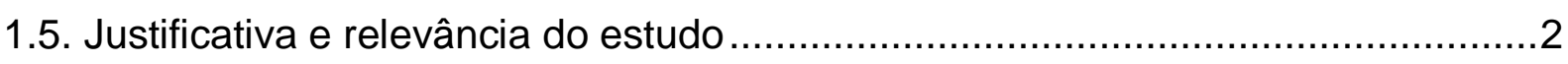

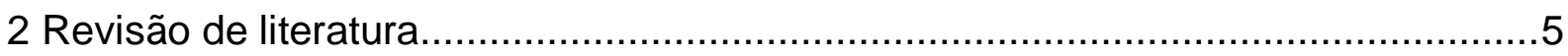

2.1. O papel da mulher na sociedade ao longo da história..................................8

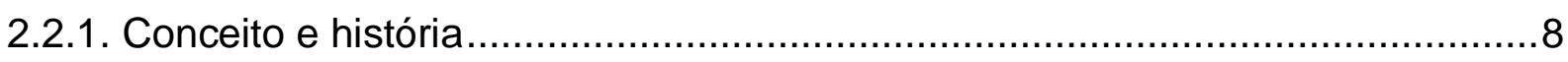

2.2.2. Perfil do empreendedor .......................................................................... 11

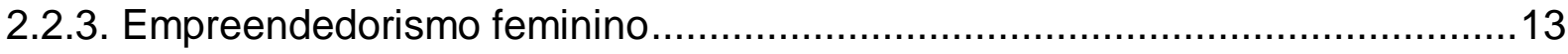

2.3. Desafios e preconceitos ................................................................... 16

3 Métodos e procedimentos de coleta e de análise de dados do estudo ..................20

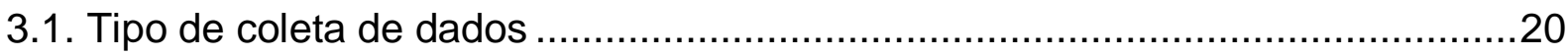

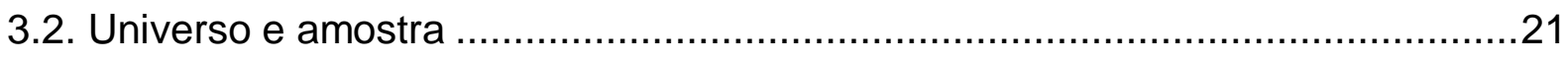

3.3. Formas de tratamento e análise dos dados coletados para o estudo ...............21

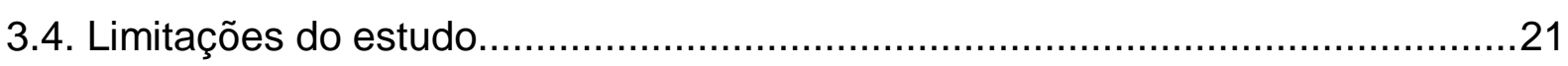

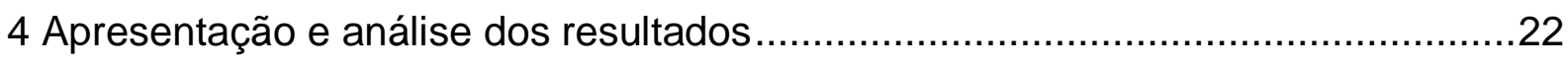

4.1. Descrição do perfil dos entrevistados ...................................................22

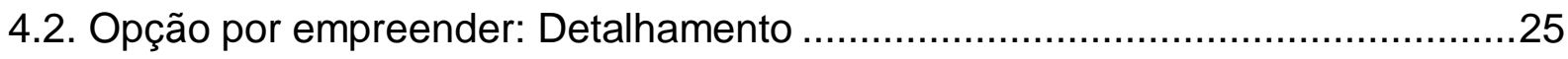

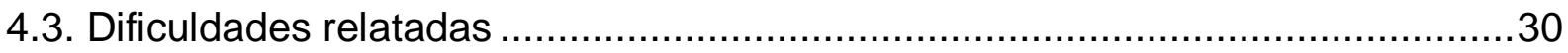

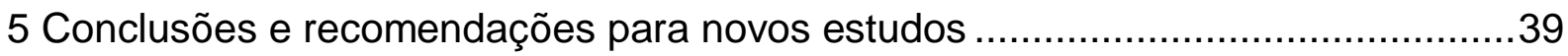

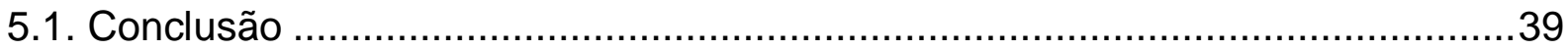

5.2. Sugestões e recomendações para novos estudos .....................................40

6 Referências Bibliográficas ....................................................................... 41 


\section{Lista de gráficos}

Gráfico 1: Número de donos de negócios no Brasil, entre 2003 a 2013, por sexo (em milhões

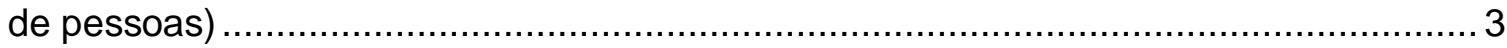

Gráfico 2: Rio de Janeiro - População total, homens e mulheres $2000-2030$....................... 3

Gráfico 3: Rendimento médio real habitual da população ocupada, por grupos de anos de estudo, segundo o sexo - (2003 e 2011) .................................................................. 7

Gráfico 4: Evolução da atividade empreendedora por oportunidade como percentual de empreendedores iniciais (TEA) - Brasil - 2002:2015

Gráfico 5: Evolução da proporção do empreendedorismo por necessidade entre os empreendedores nascentes e novos - Brasil - 2010:2015

Gráfico 6: Participação da mulher no total de donos de negócios no Brasil, entre 2003 a

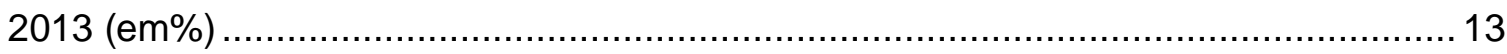

Gráfico 7: Distribuição por grau de escolaridade (2013) ................................................ 14

Gráfico 8: Distribuição por setor de atividade (2013) ...................................................... 15

Gráfico 9: Idade das entrevistadas........................................................................ 23

Gráfico 10: Estado civil das entrevistadas............................................................. 23

Gráfico 11: Número de filhos das entrevistadas .......................................................... 24

Gráfico 12: Grau de escolaridade das entrevistadas ......................................................... 24

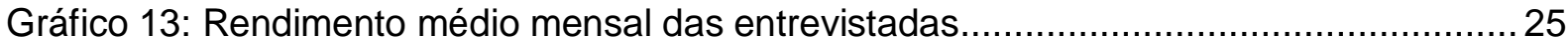

Gráfico 14: Empreendedoras por posição na ocupação do mercado de trabalho ................ 26

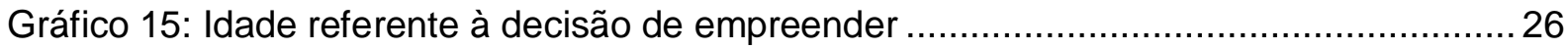

Gráfico 16: Setor de atuação das empreendedoras entrevistadas ...................................... 28

Gráfico 17: Carga diária de dedicação à vida empreendedora...........................................29

Gráfico 18: Trabalhou anteriormente com carteira assinada em empresas......................... 30

Gráfico 19: Duração de tempo trabalhando com carteira assinada .................................... 30

Gráfico 20: Percepção de diferença no tratamento por ser mulher e dona do próprio negócio

Gráfico 21: Sentiram ou sentem dificuldade de empreender por conta da idade .................. 32

Gráfico 22: Sofreram preconceito no mundo dos negócios .............................................. 32

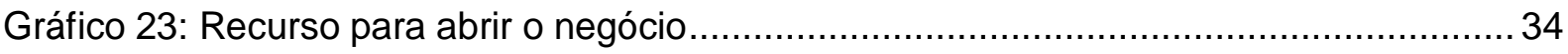


Gráfico 24: Percentual de tempo de dedicação a família e ao empreendimento 35

Gráfico 25: Oposição de alguém da família ao negócio 36

Gráfico 26: Pressão familiar por administrar o negócio 36

Gráfico 27: É difícil conciliar o trabalho com a família? 37

\section{Lista de figuras}

Tabela 1: PIB dos pequenos negócios no Brasil

4

Tabela 2: Percentual de pessoal ocupado assalariado nas empresas, segundo o sexo e o nível de escolaridade - Brasil - 2010-2012 8

Tabela 3: Percentual do total de empreendedores (TTE) segundo a busca de órgãos de apoio - Brasil - 2015

Tabela 4: Distribuição percentual dos empreendedores iniciais (TEA), empreendedores estabelecidos (TEE) e total de empreendedores (TTE) segundo características sociodemográficas - Brasil - 2015

Tabela 5: Número de donos(as) de negócio por posição na ocupação no mercado de trabalho e sexo, em 2013 14

Tabela 6: Barreiras do empreendedorismo feminino 17

Tabela 7: Informações gerais da amostra 22

Tabela 8: Número de respostas sobre as motivações para empreender. 


\section{0 tema e o problema de estudo}

\subsection{Introdução ao tema e o problema do estudo}

Ao fazer uma revisão da bibliografia, pode-se perceber que a mulher empreendedora sente dificuldades e sofre preconceitos relacionados a diversos fatores, como por exemplo os históricos, que identificam o papel dela na sociedade ao longo do tempo. A mulher servia apenas para ser esposa, arrumar a casa, procriar e cuidar dos filhos e, se assim não fosse, era julgada como prostituta ou bruxa. A mulher, antes vista apenas como dona de casa e subordinada ao marido, conquistou, ao longo dos anos, espaço no mercado de trabalho e tem buscado, cada vez mais, se desenvolver e se realizar profissionalmente. Escolas, faculdades, empresas e espaços antes inacessíveis contam, cada vez mais, com a presença das mulheres.

Segundo Botelho et al (2008), o número de empresas fundadas por mulheres é crescente. Sociedade e governos de muitos países cada vez mais reconhecem a importante da colaboração oferecida pelas mulheres na gestão de empresas e como colaboradoras no mercado de trabalho (CASSOL e HOELTGEBAUM, 2007).

Apesar da importância social e econômica que a mulher ganhou ainda mais com o empreendedorismo ainda há limitações que dificultam um número maior de mulheres a optarem pelo empreendimento. A entrada da mulher no empreendedorismo e o acumulo de responsabilidades a ela impactou seu lado familiar, por exemplo. Hoje a estrutura da família mudou e ambos a mulher e o marido trabalham. Apesar disso, não importa o nível de desenvolvimento profissional da mulher, ela ainda é a maior responsável pela casa e filhos.

Além da relação trabalho-família, outros problemas surgem no processo empreendedor feminino. Muitos são inerentes ao empreendedorismo em si, outros, porém, alinham-se ao gênero e também à idade, visto que durante o processo de empreender ainda são vitimas de preconceitos da herança histórica e conservadorismo. Segundo Alperstedt, Ferreira e Serafim (2014), é um desafio para essas mulheres administrarem seus negócios em uma atividade predominantemente masculina. A situação se torna ainda mais difícil quando elas começam a empreender cedo, ou seja, são novas e não possuem muita experiência no setor em que atuam.

Apesar disso, o cenário feminino no empreendedorismo já é mais do que uma realidade, e as empreendedoras estão em todas as partes do mundo. Pode-se dizer que a mulher está sendo capaz de demonstrar que também consegue realizar um bom trabalho 
semelhante ao do homem ou superior a ele. Do ponto de vista da mulher empreendedora quais são suas dificuldades no processo de empreender? Elas sentem que sofrem preconceito? De que tipo?

\subsection{Objetivo do estudo}

Levantar, do ponto de vista da mulher empreendedora, quais são as dificuldades no processo de empreender e identificar se sofrem preconceitos - e quais.

\subsection{Objetivos Intermediários do estudo}

A fim de atingir o objetivo principal do trabalho faz se necessário considerar os seguintes objetivos intermediários:

- Realizar uma pesquisa bibliográfica que permita uma melhor compreensão do papel da mulher ao longo da história assim como embasar a realização e análise da pesquisa de campo;

- Realizar uma pesquisa de campo junto a uma amostra de mulheres empreendedoras;

- Levantar as principais dificuldades e preconceitos vividos no dia a dia por mulheres que optam por empreender.

\subsection{Delimitação e foco do estudo}

Este estudo se delimita as dificuldades e preconceitos em relação à mulher dona do próprio negócio na visão das próprias mulheres empreendedoras, no ano de 2016, dentro do estado do Rio de Janeiro, utilizando entrevistas e dados secundários.

\subsection{Justificativa e relevância do estudo}

É importante mostrar que ainda existem dificuldades e preconceitos com relação à mulher empreendedora, fruto de fatores históricos e do conservadorismo.

Segundo dados do Serviço Brasileiro de Apoio as Micro e Pequenas Empresas (SEBRAE) de 2015, ainda é maior a participação do homem no empreendedorismo, como mostra o gráfico 1. Ainda assim existe um crescimento considerável de mulheres empreendedoras, como também mostra o gráfico, e que podem vir a sofrer preconceito pelo simples fato de serem mulheres. 


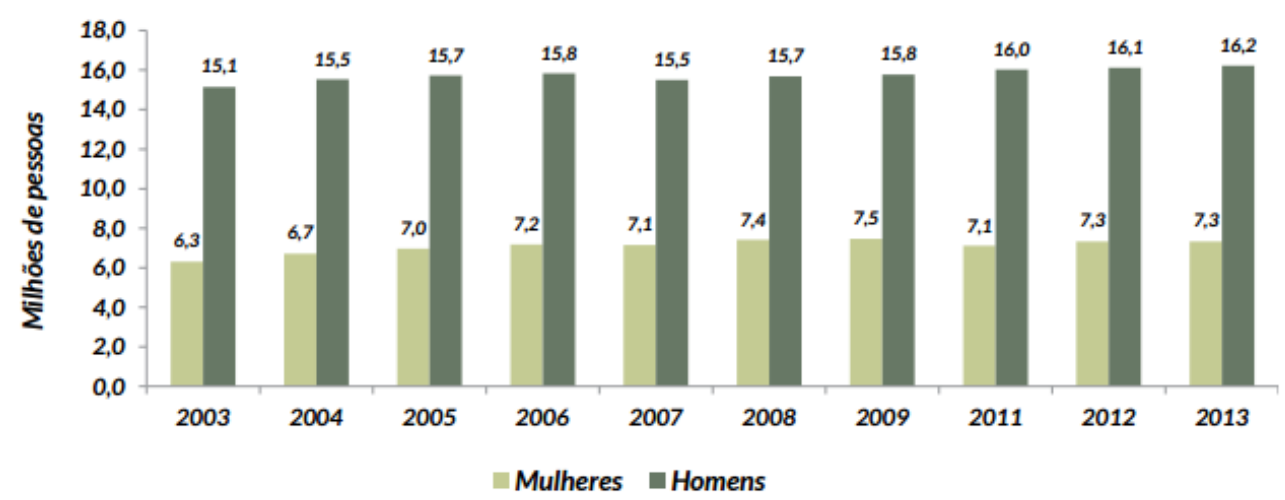

Gráfico 1: Número de donos de negócios no Brasil, entre 2003 a 2013, por sexo (em milhões de pessoas)

Fonte: SEBRAE (2015, p. 10)

Sendo assim, o estudo é relevante principalmente para empreendedoras que buscam espaço para atuar em qualquer área e desenvolver uma carreira de sucesso.

Segundo o censo 2010 no Brasil, cerca de 51\% da população são mulheres e 49\% são homens e a região sudeste é a que possui o maior número de mulheres, ou seja, apesar desse número superior de mulheres é de se atentar ao fato de que elas podem vir a sofrer preconceito devido ao gênero mesmo sendo a maioria na população brasileira. $\mathrm{O}$ gráfico 2 mostra a projeção da população de homens e mulheres até 2030 no estado do Rio de Janeiro e de acordo com a leitura dos dados há hoje um maior número de mulheres no estado e futuramente essa estimativa continuará na mesma proporção.

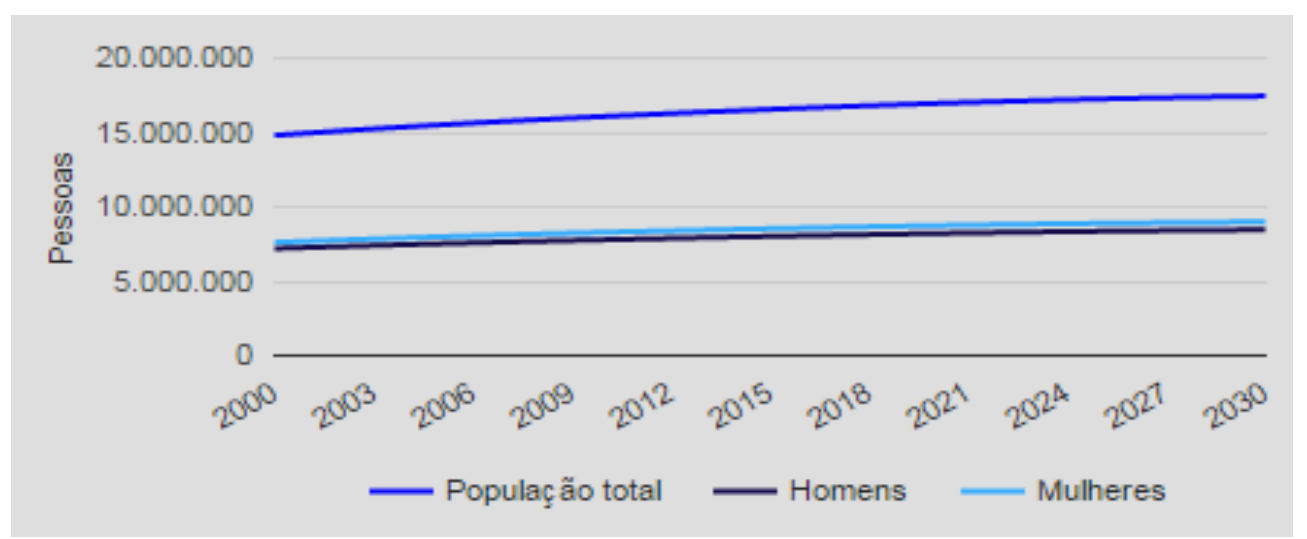

Gráfico 2: Rio de Janeiro: População total, homens e mulheres 2000-2030 Fonte: IBGE 2015

O estudo é importante também para a sociedade, pois busca uma forma de tentar identificar a existência de preconceitos que dificultam ou impedem o trabalho empreendedor desempenhado por uma mulher.

Segundo relatório do Global Entrepreneurship Monitor (GEM) de 2010, o empreendedorismo é fundamental para o crescimento econômico, pois gera empregos e renda para o país e cria oportunidades para toda a população. Machado et al (2003) destacam a importância que as mulheres como pequenas e médias empresárias possuem ao contribuírem como uma fonte importante de empregos, inovação e desenvolvimento 
econômico. A tabela 1 mostra como a economia é impactada pelas micro e pequenas empresas:

Tabela 1: PIB dos pequenos negócios no Brasil

\begin{tabular}{|l|c|c|c|}
\hline \multirow{2}{*}{$\begin{array}{l}\text { \% DO VALOR ADICIONADO DAS MICRO } \\
\text { E PEQUENAS EMPRESAS }\end{array}$} & 1985 & 2001 & 2011 \\
\hline SERVIÇOS & $5,87 \%$ & $8,3 \%$ & $10,0 \%$ \\
\hline COMÉRCIO & $5,9 \%$ & $6,8 \%$ & $9,1 \%$ \\
\hline INDÚSTRIA & $9,3 \%$ & $8,1 \%$ & $7,8 \%$ \\
\hline MICRO E PEQUENAS EMPRESAS & $21,0 \%$ & $23,2 \%$ & $27,0 \%$ \\
\hline
\end{tabular}

Fonte: SEBRAE (2014, p. 32) 


\section{Revisão de literatura}

Neste capítulo são apresentados os estudos e conceitos acerca do tema que serviram de base para a análise realizada.

\subsection{O papel da mulher na sociedade ao longo da história}

Silva et al (2005), descrevem que, para entender o papel da mulher na sociedade, tem-se que fazer uma análise do passado, dando ênfase à formação do sujeito, seus grupos e classes sociais. Na época de colonização do Brasil, elas foram tidas como objetos de domínio e submissão por receberem um conceito de não-função. Por muito tempo elas foram tratadas como o pecado em si. Esse pensamento que perdurou na sociedade, até hoje acompanha a evolução e o desenvolvimento feminino.

Beauvoir (1967, apud RODRIGUES, 2012, p. 2) destaca:

Ninguém nasce mulher: torna-se mulher. Nenhum destino biológico, psíquico, econômico define a forma que a fêmea humana assume no seio da sociedade, é o conjunto da civilização que elabora esse produto intermediário entre o macho e o castrado que qualificam de feminino. Somente a mediação de outrem pode constituir um indivíduo como um outro.

Essa citação de Beauvoir pode ser interpretada como o gênero não sendo fruto da natureza e sim de uma construção social e histórica que busca classificar a sociedade entre homens e mulheres atribuindo-lhes papeis e diferenças por sexo biológico.

Del Priore (2009) estudou as mulheres brasileiras nos séculos XVI e XVII e revelou a mentalidade da sociedade desde o início da colonização, mostrando dados associados à dominação e à opressão da mulher. A mulher era vitima constante da dor, sofrimento e humilhação. Ainda segundo o autor, ela era obrigada a se casar e constituir uma família e que sua função era procriar e a maternidade retirava o conteúdo sujo e nefasto da sexualidade.

Segundo Costa (2005) o movimento feminista surge por demandas como direitos sociais e políticos que mobilizaram mulheres de diversos países tendo seu auge na luta sufragista e sob influência das ideias iluministas, revolução francesa e americana e as primeiras manifestações no Brasil aparecem na metade do século 19. Álvarez (1990, apud TIMÓTEO, 2013, p. 93) destaca:

O movimento feminista, apesar de inserir-se no movimento mais amplo de mulheres, distingue-se por defender os interesses de gênero das mulheres, por questionar os sistemas culturais e políticos construídos a partir dos papéis de gênero historicamente atribuídos às mulheres, pela definição da 
sua autonomia em relação a outros movimentos, organizações e ao Estado, e pelo princípio organizativo da horizontalidade, isto é, da não existência de esferas de decisões hierarquizadas.

Segundo Melo (2013), as mulheres conseguiram ter autorização para frequentar a escola apenas em 1827. O movimento feminista mundial lutou por diversos direitos que as mulheres ainda eram proibidas de exercer. Entre o final de século 19 e o início do século 20, as mulheres conquistam o direito de votar. Dia 8 de março é marcado como Dia Internacional da Mulher pelas conquistas históricas dos direitos delas ao redor do mundo.

Segundo Costa (2005) no final do século 19, as mulheres brasileiras representavam uma parte significativa da força de trabalho empregada, ocupavam de forma cada vez mais crescente o trabalho na indústria, chegando a ser a maioria da mão-de-obra empregada na indústria têxtil.

Segundo Baylão e Schettino (2014), é possível perceber que a inserção da mulher no mercado de trabalho iniciou com a Revolução Industrial e ganhou destaque em época de guerras. A remuneração salarial era menor e era mais fácil disciplinar esse novo grupo trabalhador.

Segundo Costa (2005), influenciadas pelas ideias anarquistas e socialistas, algumas mulheres incorporavam às lutas sindicais na defesa de melhores salários e condições de higiene e saúde no trabalho, além do combate às discriminações e abusos a que estavam sujeitas por sua condição de gênero.

Segundo dados do IBGE (2012) percebe-se que ainda há diferença em relação ao salario recebido por homens e mulheres, tal como apresentado pelo gráfico 3. 


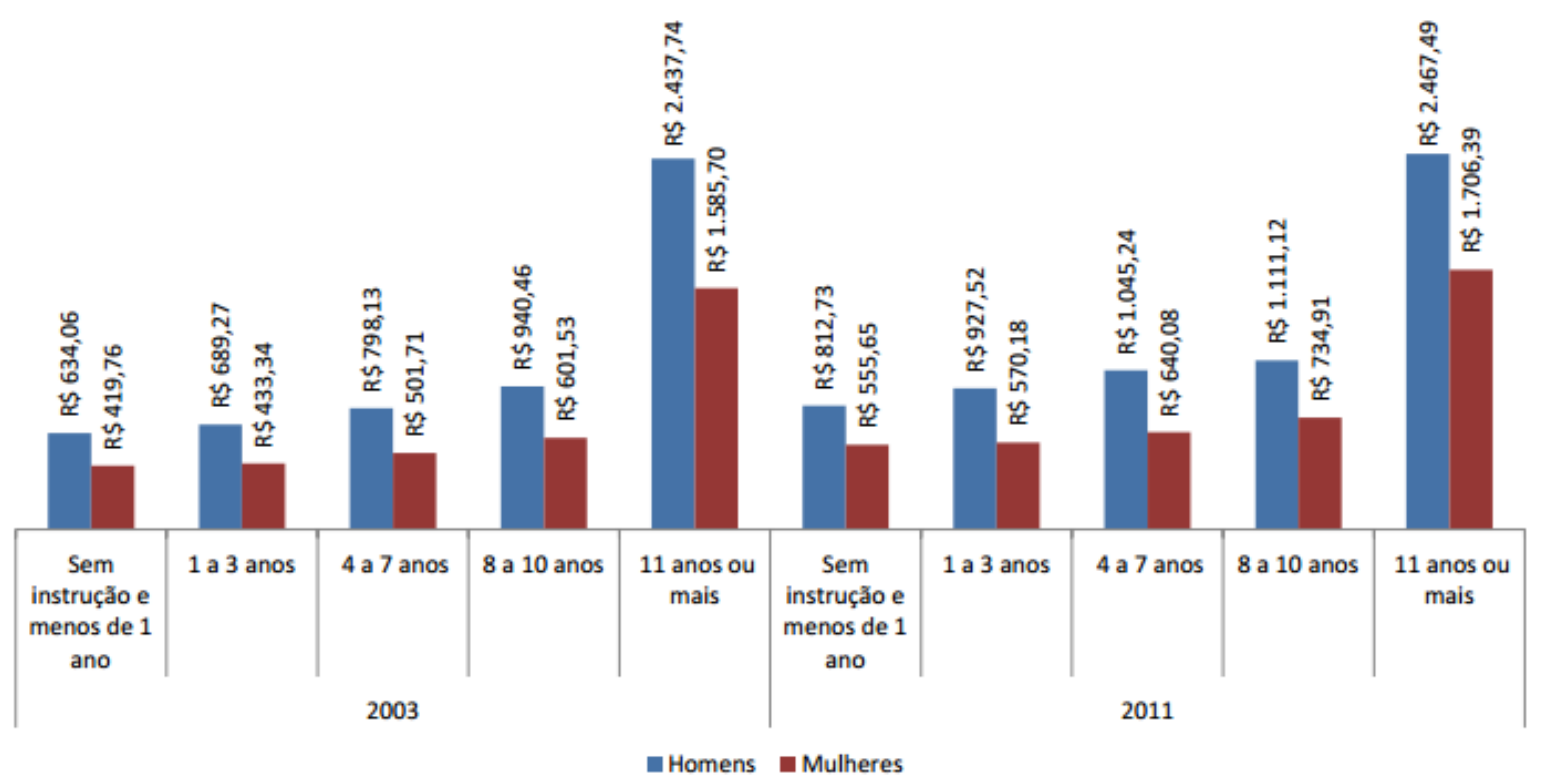

Gráfico 3: Rendimento médio real habitual da população ocupada, por grupos de anos de estudo, segundo o sexo - (2003 e 2011)

Fonte: IBGE (2012, p. 19)

O gráfico 3, além de mostrar a diferença salarial entre homens e mulheres, compara também essa diferença por anos de estudo. É possível observar que as mulheres, independente da quantidade de anos de estudo, em média, recebem menos que os homens.

Morais (2015) cita a pesquisa de 2009 feito pelo National Bureau Of Economic Research que mostra que as mulheres ganham menos que os homens por trabalharem menos horas e por interromperem a carreira mais vezes por causa da família. Ainda segundo o autor, se a dedicação dela for maior ao trabalho do que com a família, ela se sente culpada por isso.

De acordo com a tabela 2, a presença feminina no mercado de trabalho também aumentou de 2010 a 2012. Segundo estudos do SEBRAE (2013), em microempresas e pequenas empresas houve, entre 2002 a 2012, um crescimento de 43\% na participação feminina, que passou de 33.625 a 48.263. 
Tabela 2: Percentual de pessoal ocupado assalariado nas empresas, segundo o sexo e o nível de escolaridade - Brasil - 2010-2012

\begin{tabular}{|c|c|c|c|c|c|c|}
\hline \multirow{3}{*}{$\begin{array}{c}\text { Sexo } \\
\text { e } \\
\text { nivel de escolaridade }\end{array}$} & \multicolumn{6}{|c|}{ Percentual de pessoal ocupado assalariado nas empresas (\%) } \\
\hline & \multicolumn{3}{|c|}{$\begin{array}{c}\text { Ativas com } \\
10 \text { ou mais pessoas } \\
\text { ocupadas assalariadas }\end{array}$} & \multicolumn{3}{|c|}{$\begin{array}{c}\text { De alto } \\
\text { crescimento }\end{array}$} \\
\hline & 2010 & 2011 & 2012 & 2010 & 2011 & 2012 \\
\hline \multicolumn{7}{|l|}{ Sexo } \\
\hline Homem & 65,7 & 65,1 & 64,6 & 67,6 & 67,0 & 66,5 \\
\hline Mulher & 34,3 & 34,9 & 35,4 & 32,4 & 33,0 & 33,5 \\
\hline \multicolumn{7}{|l|}{ Nivel de escolaridade } \\
\hline Ensino superior completo & 10,7 & 11,0 & 11,5 & 11,1 & 9,9 & 9,3 \\
\hline Sem ensino superior & 89,3 & 89,0 & 88,5 & 88,9 & 90,1 & 90,7 \\
\hline
\end{tabular}

Fonte: IBGE (2014, p. 30)

Naisbitt e Aburdene (1994) dizem que a mulher representa a força de trabalho do futuro, pois detêm valores considerados mais femininos como o relacionamento em equipe, a socialização, participação e cooperação no ambiente de trabalho.

Já Joana et al (2013) falam da dificuldade financeira que os países estão passando e, em consequência disso, o aumento do desemprego. Os autores também citam que a alternativa para esse crescente desemprego tem sido o empreendedorismo, que será explicado a seguir.

\subsection{Empreendedorismo}

\subsubsection{Conceito e história}

Embora haja muitas definições para o que vem a ser empreendedorismo, a que é mais adequada ao presente estudo é a dada pelo GEM (2010) que conceitua empreendedorismo como:

Qualquer tentativa de criação de um novo negócio ou novo empreendimento, como por exemplo, uma atividade autônoma, uma nova empresa, ou a expansão de um empreendimento existente. Em qualquer das situações a iniciativa pode ser de um individuo, grupos de indivíduos ou por empresas já estabelecidas. (GEM, 2010, p. 215).

Segundo Dornelas (2012), o empreendedorismo surge pelas transformações que o mundo passou principalmente no século $X X$, quando foram criadas a maioria das invenções, por pessoas que possuíam uma visão futura e agiam para construírem um novo negócio. Essas pessoas são chamadas de empreendedores. Ainda segundo o autor o empreendedor é aquele que faz as coisas acontecerem, ou seja, promove a ação de transformar a ideia em realidade e possui essa visão futura da organização. $O$ empreendedorismo não é inato e pode ser ensinado e aprendido, ou seja, se alguma pessoa quiser abrir um novo negócio e 
não tem experiência anterior pode procurar aprender sobre o assunto. Consequentemente esse aprendizado gerará melhores empresários, melhores empresas e uma maior geração de riqueza ao país. Souza (2001, p. 32) destaca que "(...) no atual contexto de incertezas e desafios, o desenvolvimento e até mesmo a sobrevivência das organizações depende, em grande parte, da formação e da capacitação dos seus atores".

Segundo relatório do GEM (2010), no Brasil, o empreendedorismo cresceu e se popularizou a partir da década de $90 \mathrm{com}$ a abertura da economia, o que propiciou a criação de diversos órgãos voltados para o tema como é o caso do SEBRAE que dá suporte para o empreendedor iniciar a sua empresa e consultorias para resoluções de problemas do negócio. Para Dornelas (2012), o crescimento do empreendedorismo se acelerou na década de 90 e, em 2000, o processo continuou. Ainda segundo o autor, além das influencias das entidades como o SEBRAE, houve também a criação de programas de incubação de empresas, entre outros. A tabela 3 mostra que é grande o percentual dos empreendedores que buscam esses órgãos, e principalmente o SEBRAE.

Tabela 3: Percentual do total de empreendedores (TTE) segundo a busca de órgãos de apoio - Brasil $-2015$

\begin{tabular}{|lc|}
\hline \multicolumn{1}{|c|}{ Órgãos de apoio } & 2015 \\
\hline \multicolumn{2}{|c|}{ Procurou algum órgão de apoio } \\
\hline \multicolumn{2}{|c|}{ Principais órgãos de apoio procurados ${ }^{1}$} \\
\hline SEBRAE & 14,1 \\
SENAC & 66,2 \\
SENAI & 13,9 \\
Outros $^{2}$ & 13,8 \\
\hline
\end{tabular}

Fonte: GEM (2015, p. 15)

Segundo Dornelas (2012) a motivação para abrir um novo negócio pode vir com o aumento do desemprego, visto que os desempregados começavam um novo negócio sem experiência anterior no ramo. Pode ainda derivar do avanço da internet, que interessa e estimula jovens a criar um novo negócio e também aqueles que querem dar continuidade ao negócio da família.

Para Dornelas (2012), um fator que colaborou para o crescimento do empreendedorismo no país foi a criação do Programa Empreendedor Individual, instituído através da Lei Complementar № 128/2008 que alterou a Lei Geral da Micro e Pequena Empresa (Lei complementar no 123/2006) com objetivo de formalizar os empreendedores que estavam na informalidade. Outros fatores foram a Copa do Mundo de 2014 e as Olimpíadas de 2016 que são grandes eventos que estimulam novas oportunidades empreendedoras e a criação e desenvolvimento de novos negócios no país.

Segundo relatório da GEM de 2015, a taxa de empreendedorismo do Brasil foi de $39,3 \%$ enquanto que em 2014 foi $35,5 \%$, o que representou um aumento significativo no 
empreendedorismo brasileiro. Parte desse aumento foi devido ao aumento no número de empreendedores iniciais que cresceu consideravelmente de 2014 para 2015. Pelo GEM (2015) os empreendedores são classificados como iniciais (novos e nascentes) e estabelecidos. O empreendedor nascente é aquele que é envolvido na estruturação de um negócio do qual é proprietário, mas que ainda não pagou salários, pró-labores ou qualquer outra forma de remuneração por mais de três meses. Já o empreendedor novo administra e é proprietário de um novo negócio que pagou salários, gerou pró-labores ou qualquer outra forma de remuneração por mais de três e menos de 42 meses. Os estabelecidos administram e são proprietários do negócio consolidado que já pagam salários, pró-labores e outras formas de remuneração aos proprietários por mais de 42 meses. A recente pesquisa da GEM (2015) mostra a evolução da motivação empreendedora de empreendedores iniciais sob 0 aspecto oportunidade $x$ necessidade. Os gráficos 4 e 5 mostram essa evolução:

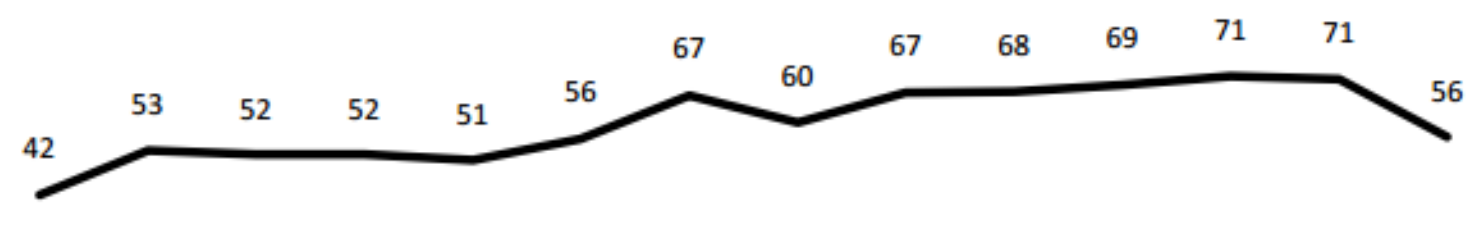

\begin{tabular}{llllllllllllll}
\hline 2002 & 2003 & 2004 & 2005 & 2006 & 2007 & 2008 & 2009 & 2010 & 2011 & 2012 & 2013 & 2014 & 2015
\end{tabular}

Gráfico 4: Evolução da atividade empreendedora por oportunidade como percentual de empreendedores iniciais (TEA) - Brasil - 2002:2015

Fonte: GEM (2015, p. 11)

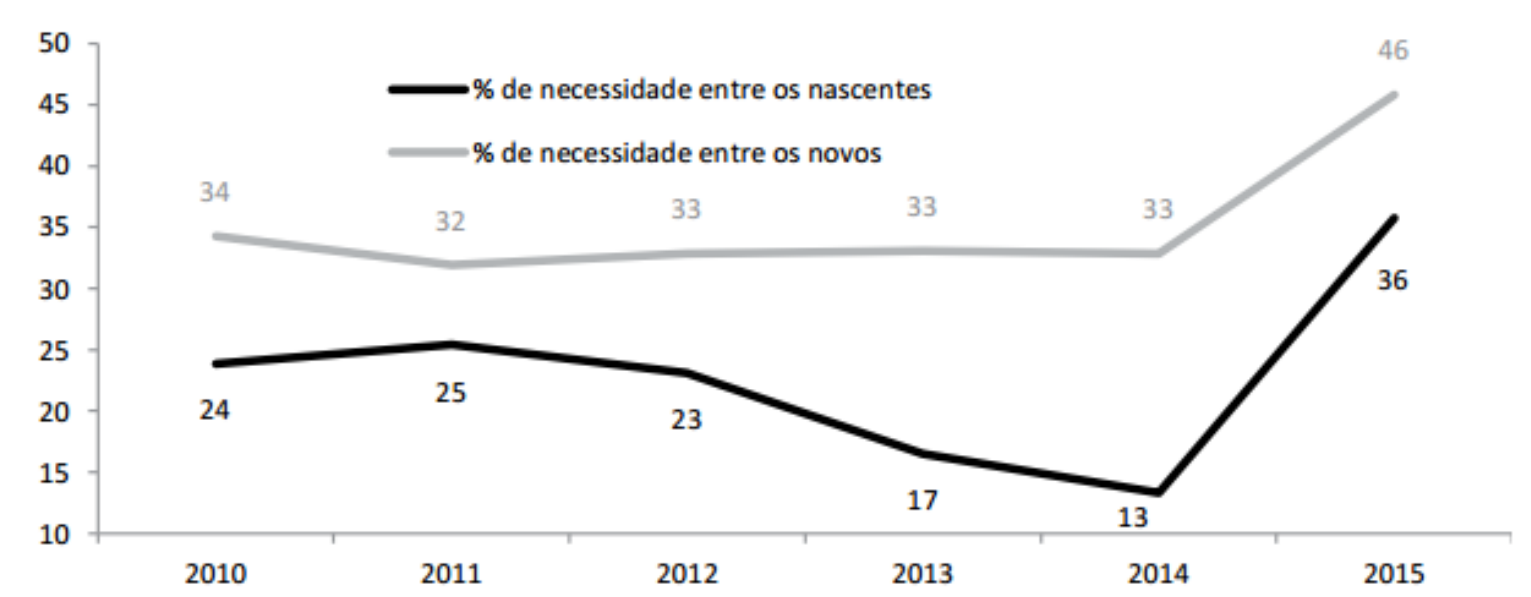

Gráfico 5: Evolução da proporção do empreendedorismo por necessidade entre os empreendedores nascentes e novos - Brasil - 2010:2015

Fonte: GEM (2015, p. 11)

Como mostram os gráficos 4 e 5, a motivação de empreender por necessidade aumentou mais que a por oportunidade e as taxas de empreendedorismo no Brasil 
aumentaram entre 2014 e 2015, ou seja, há um maior número de empreendedores iniciais motivados pela necessidade.

Para entender melhor o empreendedorismo e seu respectivo crescimento é importante também conhecer o perfil do empreendedor que promove a ação para a criação e manutenção do negócio.

\subsubsection{Perfil do empreendedor}

O perfil empreendedor expõe traços característicos como também características de comportamento e maneira de agir desses empreendedores.

Segundo Bueno, Leite e Pilatti (2004) o empreendedor possui características que o definem como tal. Entre elas, o desejo de estar sempre se aprimorando e se atualizando buscando com isso aprendizado.

Para Filion (1999) o empreendedor é aquele que possui criatividade, conseguindo detectar oportunidades de negócios, toma decisões de riscos e é uma pessoa de visão. Nessa linha de pensamento Schumpeter (1982, apud PEDROSO, MASSUKADO e MUSSI, 2009) diz que o empreendedor é um inovador ao combinar recursos numa maneira nova e original. Ainda de forma semelhante, Drucker (1986) comenta que a inovação é o instrumento específico dos empreendedores. Para o autor, os empreendedores precisam buscar a inovação, conhecer seus princípios e colocá-los em prática.

Já Kassai (1996) destaca as características mais presentes em pesquisas que procuram examinar o perfil do empreendedor: necessidade de auto realização, necessidade de desenvolver sua criatividade, autoconfiança, dedicação, busca de conhecimento, iniciativa, independência e disposição para assumir riscos. 
Tabela 4: Distribuição percentual dos empreendedores iniciais (TEA), empreendedores estabelecidos (TEE) e total de empreendedores (TTE) segundo características sociodemográficas - Brasil - 2015

\begin{tabular}{|c|c|c|c|}
\hline \multirow{2}{*}{ Caracteristicas do empreendedor } & \multicolumn{3}{|c|}{ Brasil 2015} \\
\hline & TEA & TEE & TTE \\
\hline \multicolumn{4}{|l|}{ Gênero } \\
\hline Masculino & 51,0 & 55,7 & 53,3 \\
\hline Feminino & 49,0 & 44,3 & 46,7 \\
\hline Total & 100,0 & 100,0 & 100,0 \\
\hline \multicolumn{4}{|l|}{ Faixa etária } \\
\hline 18 a 24 anos & 19,2 & 4,9 & 12,6 \\
\hline 25 a 34 anos & 32,8 & 17,0 & 25,7 \\
\hline 35 a 44 anos & 24,3 & 27,6 & 25,5 \\
\hline 45 a 54 anos & 15,2 & 30,8 & 22,6 \\
\hline 55 a 64 anos & 8,4 & 19,6 & 13,6 \\
\hline Total & 100,0 & 100,0 & 100,0 \\
\hline \multicolumn{4}{|l|}{ Renda familiar } \\
\hline Até 3 salários mínimos & 60,8 & 54,6 & 58,1 \\
\hline Mais de 3 ate 6 salários minimos & 28,7 & 36,5 & 32,1 \\
\hline Mais de 6 até 9 salários mínimos & 7,1 & 5,2 & 6,2 \\
\hline Mais de 9 salários mínimos & 3,4 & 3,7 & 3,6 \\
\hline Total & 100,0 & 100,0 & 100,0 \\
\hline \multicolumn{4}{|l|}{ Nivel de escolaridade $^{T}$} \\
\hline Educo & 26,0 & 35,9 & 30,6 \\
\hline Educ1 & 18,5 & 20,4 & 19,7 \\
\hline Educ2 & 48,8 & 38,5 & 43,7 \\
\hline Educ 3+ & 6,7 & 5,1 & 6,0 \\
\hline Total & 100,0 & 100,0 & 100,0 \\
\hline \multicolumn{4}{|l|}{ Estado civil } \\
\hline Casado & 37,0 & 47,4 & 41,8 \\
\hline União estável & 18,1 & 16,0 & 17,3 \\
\hline Divorciado & 4,5 & 9,2 & 6,8 \\
\hline Solteiro & 39,2 & 22,6 & 31,1 \\
\hline Viúvo & 1,0 & 4,0 & 2,4 \\
\hline Outros & 0,2 & 0,8 & 0,5 \\
\hline Total & 100,0 & 100,0 & 100,0 \\
\hline \multicolumn{4}{|l|}{ Cor } \\
\hline Branca & 38,4 & 38,0 & 38,2 \\
\hline Preta & 9,4 & 8,0 & 8,6 \\
\hline Parda & 52,0 & 52,7 & 52,4 \\
\hline Outras & 0,2 & 1,3 & 0,7 \\
\hline Total & 100,0 & 100,0 & 100,0 \\
\hline
\end{tabular}

'Educo = Nenhuma educaçăo formal e primeiro grau incompleto; Educ1 = Primeiro grau completo e segundo lincompleto; Educ2 = Segundo grau completo e superior incompleto; Educ3 + = Super ior completo, especialização incompleta e completa, mestrado incompleto e completo, doutor ado incompleto e doutorado completo.

Fonte: GEM (2015, p. 14)

A tabela 4 mostra as características do empreendedor brasileiro e aponta que a maioria dos empreendedores é do sexo masculino correspondendo a 53,3\% do total contra $46,7 \%$ do sexo feminino e a maioria possui de 25 a 34 anos. No que se refere a renda familiar a maior parte deles possui até 3 salários mínimos, o que está entre as classes $C, D$ ou E. Eles também possuem segundo grau completo e superior incompleto e a maioria é casada.

Ainda segundo o citado relatório sobre a percepção das pessoas com relação ao empreendedorismo, os brasileiros são favoráveis e tem uma visão positiva a respeito dos indivíduos envolvidos com negócios próprios. Isso pode ser observado no percentual de $70 \%$ e $80 \%$ dos brasileiros concordarem que abrir um negócio é uma opção desejável de 
carreira, valorizam o sucesso dos empreendedores e acompanham na mídia histórias sobre empreendedores bem sucedidos.

Estudo do IBGE (2014, apud, SEBRAE, 2015, p. 7) aponta que em 2012 havia cerca de 23,5 milhões de pessoas donas do próprio negócio. Desse total, cerca de 7,3 milhões (31\%) eram mulheres e 16,2 milhões (69\%) homens. Para detalhar um pouco mais esse assunto, será abordado o empreendedorismo feminino na sequência.

\subsubsection{Empreendedorismo feminino}

Machado et al (2003) dizem que as mulheres representam a metade da população mundial e é crescente o número de empresas que são criadas e administradas por elas.

Segundo relatório do SEBRAE (2015) a tendência do aumento da participação da mulher no empreendedorismo como dona do próprio negócio é compatível com a de expansão da participação das mulheres no mercado de trabalho, que está diretamente ligada ao menor número de filhos que estão tendo, à redução do tamanho da família, ao crescimento do número de casais sem filhos, famílias unipessoais, a urbanização e a maior escolaridade.

Morais (2015) diz que o empreendedorismo no Brasil vem aumentando, com destaque para as mulheres que através da necessidade ou falta de oportunidade nas organizações optam pela carreira empreendedora.

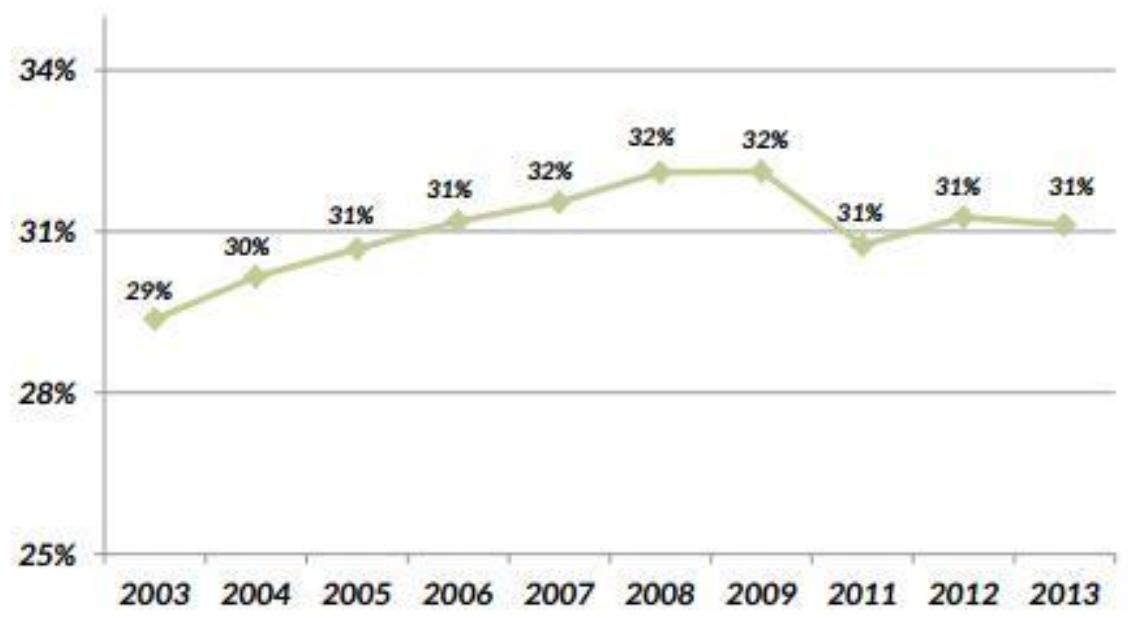

Gráfico 6: Participação da mulher no total de donos de negócios no Brasil, entre 2003 a 2013 (em\%) Fonte: SEBRAE (2015, p. 11)

Segundo o GEM (2010), o empreendedorismo feminino tem crescido nas ultimas décadas e está diretamente ligado ao investimento delas na sua própria educação. Mussak (2004) afirma que a educação feminina vem, visivelmente, apresentando melhores indicadores, seja na expansão dos níveis educacionais ou na maior oferta de cursos superiores, preparando-as e qualificando-as mais adequadamente para o mercado de trabalho. 


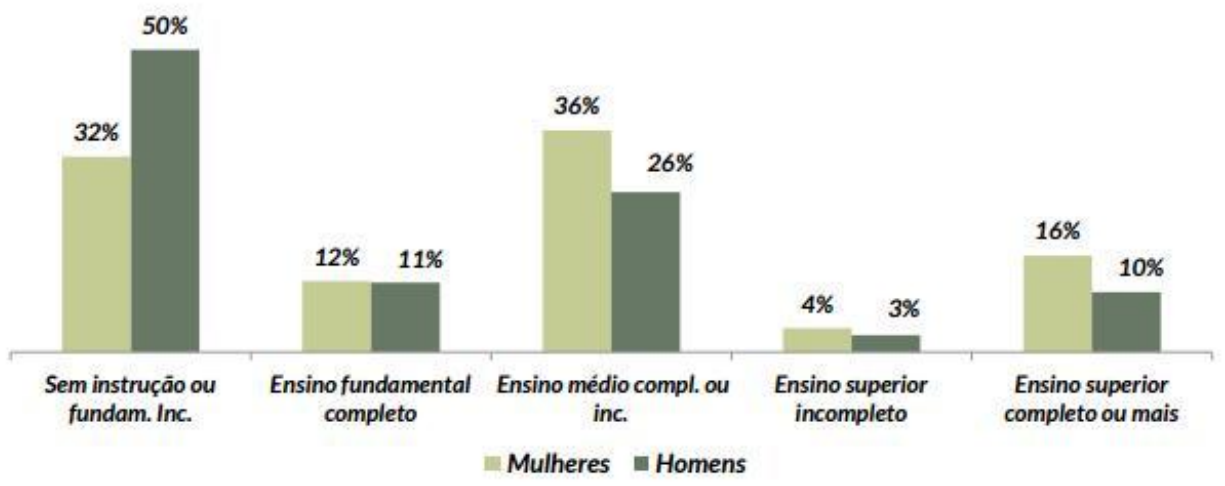

Gráfico 7: Distribuição por grau de escolaridade (2013)

Fonte: SEBRAE (2015, p. 13)

Observa-se no gráfico 7 que a mulher empreendedora investe mais em educação que o homem. O percentual de mulheres no mesmo nível educacional que os homens, considerando os cinco níveis apresentados, é superior em quatro.

Segundo o GEM (2008) as mulheres brasileiras estão classificadas em 7ํ lugar no ranking mundial como mais empreendedoras. Morais (2015) diz que a faixa de idade em que uma mulher empreende é de 35 a 40 anos, um pouco mais tarde que o homem por razões pessoais como a família.

Tabela 5: Número de Donos(as) de Negócio por posição na ocupação no mercado de trabalho e sexo, em 2013

\begin{tabular}{|l|r|r|r|r|r|r|r|}
\hline & \multicolumn{3}{|c|}{ Mulher } & \multicolumn{2}{|c|}{ Homem } & \multicolumn{2}{c|}{ TOTAL } \\
\hline Conta-própria & 6.290 & $86 \%$ & 13.634 & $84 \%$ & 19.924 & $85 \%$ \\
\hline Empregadores & 1.039 & $14 \%$ & 2.584 & $16 \%$ & 3.623 & $15 \%$ \\
\hline TOTAL & 7.329 & $100 \%$ & 16.218 & $100 \%$ & 23.547 & $100 \%$ \\
\hline
\end{tabular}

Fonte: SEBRAE (2015, p. 12)

Segundo dados apresentados na tabela 5, o tipo de empreendedorismo que predomina entre as mulheres brasileiras é por conta-própria.

Ainda segundo esse mesmo relatório o rendimento médio da mulher empreendedora também cresceu em 54\% de 2003 a 2013 passando de $\mathrm{R} \$ 952,00$ para $\mathrm{R} \$ 1.464,00$.

Hisrich (2004) aponta que existe uma diferença da natureza do empreendimento entre homens e mulheres e que elas possuem empreendimentos de menor porte e, consequentemente, menor lucro líquido. Apesar disso, o setor que mais cresce é o de serviço onde as mulheres exibem melhores resultados. Morais (2015) destaca que homens tem tendência para fabricação, finanças ou áreas técnicas enquanto as mulheres têm tendência para áreas ligadas a prestação de serviços.

No gráfico 8 pode-se observar que o setor de serviço é liderado pelas mulheres empreendedoras e, segundo os dados da pesquisa realizada pelo SEBRAE (2015), as atividades mais frequentes conduzidas por mulheres são atividades historicamente associadas ao sexo feminino como o serviços de beleza (cabeleireiras e manicures) com 
$36 \%$ do total de empreendedoras. Já os homens lideram o setor de construção ligado a atividades da construção, fabricação de produtos de metal, máquinas e equipamentos.

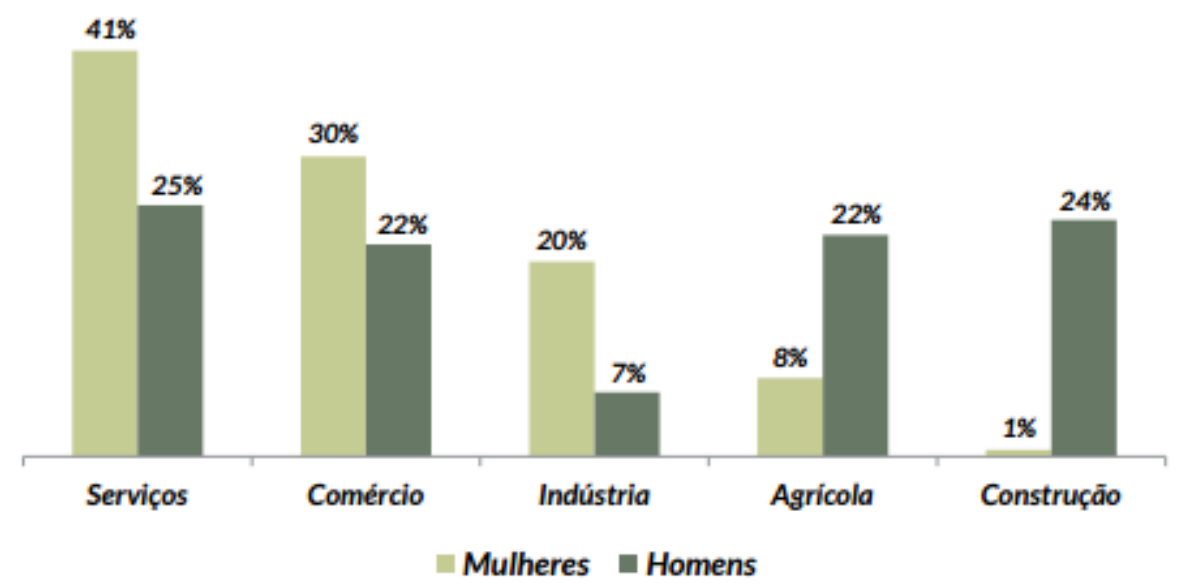

Gráfico 8: Distribuição por setor de atividade (2013)

Fonte: SEBRAE (2015, p. 21)

De acordo com Hisrich (2004) os empreendedores estão normalmente inseridos em algo relacionado ao seu emprego anterior ou até mesmo complementam o mesmo. Já as empreendedoras abandonam sua antiga ocupação com alguma frustração e assim passam a buscar realização pessoal e não apenas profissional. Machado et al (2003) dizem que as mulheres criam novas empresas por diferentes razões e esses são alguns exemplos de motivos tanto mundialmente como no Brasil: desejo de realização pessoal e independência, oportunidade de mercado, dificuldade em ascender profissionalmente em outras empresas e por necessidade. O Relatório do GEM (2015) apontou que entre empreender por necessidade ou oportunidade, as mulheres têm empreendido mais pela necessidade.

Segundo Jonathan (2005) as mulheres empreendedoras caracterizam-se por serem destemidas, autoconfiantes, apaixonadas e identificadas com seus empreendimentos.

De acordo com a GEM (2010), as mulheres quando trabalham como empregadoras, parecem ter um estilo de gerenciamento mais participativo, importam-se mais com os empregados e clientes e apontam mais razões familiares para começar um negócio. Machado (1999, apud MARCIA, ADRIANA e RIVANDA, 2011) fala sobre o perfil da mulher empreendedora e suas características e relata que para elas é importante na tomada de decisão a valorização do indivíduo e que são mais conservadoras em uma situação de risco.

(...) Na gestão do conhecimento empresarial, a mulher ganha cada vez mais importância estratégica, pois trabalha naturalmente com a diversidade, processos multifuncionais, além de compartilhar suas experiências e habilidades com os demais componentes da empresa/equipe. Por ser o sexo considerado sensível, ela permite que as equipes de trabalho que atuam isoladamente e com heterogeneidades, se constituam numa equipe unida e atuando de forma sinérgica, com soluções criativas para resoluções de problemas, antes considerados insolúveis. (SILVA, 2007, p.17). 
Cassol (2006) ressalta que no empreendedorismo feminino a habilidade gerencial merece destaque, pois é ela que garante o sucesso do empreendimento. Já para Leite (1994), como as mulheres levam em consideração a opinião do grupo, ou seja, de todos, elas são mais lentas no processo decisório.

Segundo dados do IBGE (2013) metade das empresas fecha as portas no Brasil após quatro anos. Dornelas (2013) diz que as empresas administradas por mulheres sobrevivem mais tempo no mercado. Ele destacou um estudo realizado pela Escola de Negócios da Universidade Leeds no Reino Unido, em fevereiro de 2013, que mostrou que empresas startup com uma mulher na diretoria têm $27 \%$ menos risco de falir se comparadas com empresas que possuem apenas homens no corpo diretivo.

Andreoli e Borges (2007) destacam que as mulheres possuem grande capacidade empreendedora, inovando e aperfeiçoando o mundo dos negócios. Peters (2004) imagina uma doutrina de empreendimento que tem nas mulheres as respostas frente aos problemas da escassez de talento e aos problemas da escassez de líderes.

Segundo Alperstedt, Ferreira e Serafim (2014) apesar disso o processo empreendedor das mulheres enfrenta desafios pela construção histórica atrelada ao gênero feminino. O próximo tópico falará sobre essas dificuldades e preconceitos com relação às mulheres empreendedoras.

\subsection{Desafios e preconceitos}

O núcleo de Estudos da Mulher e Relações Sociais de Gênero, da Universidade de São Paulo (NEMGE) destaca preconceito e estereótipo como "(...) uma opinião predeterminada, que afeta as relações interpessoais. O estereótipo aparece como uma forma rígida, anônima, reproduz imagens e comportamentos, separa os indivíduos em categorias". (USP-NEMGE, 1996, p.3).

Nessa mesma linha de pensamento Queiroz (1995, p. 16) destaca “(...) preconceito é um conceito prévio, formulado sem o cuidado de permitir que os fatos sejam investigados e possam contrariar nossos julgamentos ou opiniões". Formiga, Neta e Medeiros (2008) diz que o preconceito pode ser então oriundo de construções sociais influenciadas pelas normas vigentes.

Formiga (2004, apud FORMIGA, NETA e MEDEIROS, 2008) diz que hoje é mais difícil identificar um indivíduo preconceituoso, pois segundo ele não houve diminuição do preconceito e sim uma reconfiguração dessas formas preconceituosas que se tornaram mais sutis e modernas.

Lima e Vala (2004) também separa o preconceito em tipos: preconceito contra a mulher ou sexismo, homofobia, racismo, ageísmo entre outros. 
Queiroz (1995) diz que as diferenças de gênero são consequência do dimorfismo sexual da nossa espécie atribuindo a mulher uma inferioridade de base biológica.

Cramer et al (2012) dizem que as mulheres necessitam estar sempre provando que são capazes de administrar seus negócios para conseguirem conquistar seus espaços como empreendedoras. A tabela 6 mostra algumas barreiras e desafios que enfrentam as mulheres empreendedoras.

Tabela 6: Barreiras do Empreendedorismo Feminino

\begin{tabular}{|c|c|}
\hline $\begin{array}{l}\text { - } \begin{array}{l}\text { Ausência de modelos de } \\
\text { empreendedoras; }\end{array} \\
\end{array}$ & $\begin{array}{l}\text { - Dificuldades de obter confiança de } \\
\text { clientes e fornecedores, }\end{array}$ \\
\hline - Falta de treinamento adequado; & - Falta de tempo pra si; \\
\hline $\begin{array}{l}\text { - Divisão desvantajosa de tarefas } \\
\text { domésticas; }\end{array}$ & $\begin{array}{l}\text { - Problemas culturais que afetam } \\
\text { seu desempenho; }\end{array}$ \\
\hline $\begin{array}{l}\text { - Dominação social dos homens na } \\
\text { área de negócios: }\end{array}$ & $\begin{array}{l}\text { - Dificuldade de auto-confiança e } \\
\text { aceitação; }\end{array}$ \\
\hline - Falta de suporte afetivo e social; & $\begin{array}{l}\text { - Dificuldade para atuar no } \\
\text { mercado; }\end{array}$ \\
\hline $\begin{array}{l}\text { - Dificuldades para conseguir } \\
\text { financiamentos; }\end{array}$ & - Acesso a rede e falta de mentores; \\
\hline - Obrigação versus Desejo: & - Tamanho das empresas. \\
\hline - Trabalho versus Familia ${ }_{j}$ & \\
\hline
\end{tabular}

Fonte: Silva (2007, p.49)

De acordo com Machado (2002) a falta de apoio dos familiares, amigos ou dos bancos que inviabilizam a concessão de empréstimos financeiros para elas é a crítica mais indicada pelas mulheres. A falta de confiança dos clientes, fornecedores e acionistas vem em seguida. Essas dificuldades estão diretamente ligadas a uma sociedade predominantemente machista.

Machado et al (2003) verificaram que a principal fonte de recurso para a mulher conseguir abrir sua própria empresa tanto no Brasil, Canadá e França é o capital proveniente de economias pessoais, empréstimos familiares ou de amigos. O relatório da GEM (2010) diz que as mulheres tem maior dificuldade para acessar recursos financeiros, humanos e capital social do que os homens. Esse mesmo relatório aponta que $25 \%$ das mulheres acreditam que são tratadas de formas diferentes pelas instituições financeiras.

Segundo Brush et al (2000, apud JONATHAN, 2003), no que tange ao tema investimentos na área tecnológica há a falta de investimento em empreendimentos femininos. Há uma determinada quantidade de investimentos em empreendimentos femininos não proporcional ao número de mulheres donas do próprio negócio. Ainda segundo o autor se tratando de empréstimos femininos, eles são percebidos como mais arriscados por serem considerados de menor porte e recentes no mercado o que geraria maiores taxas de empréstimo e as mulheres acabariam tendo dificuldade em aceitá-los. 
Segundo Botelho et al (2008), é um desafio para as empreendedoras administrarem seus negócios num espaço predominantemente masculino. Nessa linha de pensamento Andreoli e Borges (2007) dizem que o ambiente empresarial possui caráter machista e ambiente propício a discriminação, o que é uma dificuldade para as mulheres. Langowits (2004) diz que o potencial e a boa rentabilidade da empresa não estão ligados ao sexo já que existem mulheres em carreiras de sucesso na indústria de tecnologia.

Segundo Leal (2001, apud JONATHAN, 2003) fala que as mulheres têm aumentado suas atividades no setor tecnológico especialmente em tecnologia da informação onde há um estereótipo e preconceito de gênero. Ainda segundo o autor, elas criam seus próprios negócios no setor tecnológico e sofrem com discriminação de gênero e de idade.

O desafio da aceitação da mulher no mercado de trabalho seja como empregada ou empregadora ou autônoma variam de sociedade para sociedade como mostra o trecho que segue:

As sociedades diferem em suas percepções e costumes sobre o trabalho feminino e a sua participação em negócios. Os vários níveis de educação e desenvolvimento podem influenciar consideravelmente as crenças sociais, o que está geralmente associado ao grau de aceitação sobre a carreira da mulher. No entanto, em alguns casos, as mulheres investem no empreendedorismo, independentemente de percepção, ou simplesmente porque suas famílias necessitam de suas rendas. Além disso, a aceitação da sociedade sobre deixar os cuidados com os filhos com outras pessoas enquanto desenvolvem uma carreira, adicionada ao custo de disponibilidade de serviços com esse fim, podem pesar significativamente. A mulher empreendedora também necessita da cooperação e apoio de investidores e financiadores, empregados, fornecedores e consumidores. Quando estes fatores agem como impedimento, a sociedade perde uma oportunidade de ganhar a energia empreendedora de metade de sua população. (GEM GLOBAL, apud GEM, 2010, p. 46)

Para Alperstedt, Ferreira e Serafim (2014), além da questão do gênero, para ambos os sexos existe a dificuldade de credibilidade devido à falta de experiência anterior no negócio que se está empreendendo e a questão da idade. Além disso, também existe preconceito relacionado ao fato de algumas empreendedoras serem interioranas, com pouco conhecimento de estudo e pouco recurso financeiro.

Machado (2002) diz também que as dificuldades relacionadas as mulheres empreendedoras estão geralmente ligadas aos pais, maridos e filhos devido a preocupação da mulher vinculada a constituição de uma família. Segundo Gomes (2004), a mulher que trabalha fora tem grande dificuldade de conciliar trabalho e família. Para os homens essa dificuldade não tem tanta frequência.

Estudo de Buttner e Moore (1997) destacam a influência familiar como a pressão do marido e dos filhos como uma dificuldade que essas mulheres empreendedoras sofrem ao administrarem seus negócios. Nessa linha de pensamento Cramer et al (2012) dizem que a mulher necessita estar com a família porém em função do negócio elas abrem mão do 
tempo destinado a convivência com a família e de suas tarefas de "mãe" e "esposa" para se dedicarem ao empreendimento. Powell e Eddleston (2013) relatam que o apoio familiar para ambos os sexos está diretamente ligada ao sucesso empreendedor.

Silva (2007) diz ainda que elas sofrem também com estresse de lidar com trabalho empresarial e o cuidado da casa, pois dedicam-se ao trabalho e quando chegam em casa elas ainda tem que lidar com as tarefas domésticas. 


\section{Métodos e procedimentos de coleta e de análise de dados do estudo}

Este capítulo informa sobre as decisões como acerca do estudo que foi realizado. Dividido em tipo de coleta de dados, universo e amostra, instrumentos de coleta de dados, forma de tratamento, análise dos dados e, por ultimo, as limitações do estudo.

\subsection{Tipo de pesquisa e forma de coleta de dados}

Segundo Vergara (2000), os critérios de classificação de pesquisa são divididos quanto aos fins e aos meios.

Quanto aos fins a pesquisa é descritiva e explicativa e, segundo Vergara (2000), a pesquisa descritiva expõe características de determinada população ou fenômeno e também pode fazer correlações entre as variáveis. Já a pesquisa explicativa, ainda segundo o autor, tem como objetivo justificar motivos, buscando esclarecer quais fatores contribui para ocorrência de determinado fenômeno.

Quanto aos meios de investigação, trata-se de uma pesquisa de campo realizada por meio de entrevistas e bibliográfica por meio de livros, artigos, redes eletrônicas e revistas especializadas em empreendedorismo feminino.

Ainda segundo Vergara (2000), a coleta de dados trata da forma de obter os dados necessários para responder ao problema de pesquisa.

A entrevista caracteriza-se por ser um instrumento de coleta de dados no qual o entrevistador faz perguntas ao entrevistado que, oralmente, lhe responde. Segundo Dencker (2000), as entrevistas podem ser estruturadas, constituídas de perguntas definidas ou semiestruturadas, permitindo uma maior liberdade ao pesquisador.

Os dados foram coletados por meio de entrevistas estruturadas, pois foi elaborado um roteiro a ser seguido no momento da entrevista. Foi realizada uma entrevista teste a fim de verificar a adequação das perguntas e a clareza das mesmas e, após o teste do instrumento de coleta de dados inicialmente elaborado, foram realizados ajustes e o roteiro utilizado segue no Apêndice 1. As entrevistas tiveram a duração de aproximadamente uma hora. Antes de cada entrevista era explicado o objetivo e a relevância da pesquisa e a importância da colaboração, evitando, contudo, fornecer informações e opiniões que pudessem levar a algum viés nas respostas das entrevistadas. Com a permissão dos entrevistados as entrevistas foram gravadas e posteriormente transcritas. 


\subsection{Universo e amostra}

Segundo Vergara (2000) o universo e amostra é a definição da população total e a população amostral. A população total é o conjunto de elementos que possuem as características objetivo de estudo. Dessa forma, o universo dessa pesquisa é formado por mulheres empreendedoras no estado do Rio de Janeiro.

Ainda segundo Vergara (2000) a população amostral é uma parte da população total segundo critério de representatividade. A amostra escolhida seguiu o critério não probabilístico por acessibilidade devido à facilidade de acesso a elas. A amostra foi formada por 16 mulheres empreendedoras residentes no estado do Rio de Janeiro. De outra maneira, a dificuldade de se conseguir os dados seria muito grande.

\subsection{Formas de tratamento e análise dos dados coletado}

Segundo Vergara (2000) o tratamento dos dados refere-se a como tratá-los após coletados, o que pode ocorrer de forma quantitativa e qualitativa. A quantitativa utiliza-se de procedimentos estatísticos enquanto a qualitativa codifica os dados e deixa-os de forma mais estruturada analisando-os.

Os dados foram tratados levando em consideração o referencial teórico e a análise de frequência das respostas, o que permitiu a geração de alguns gráficos.

\subsection{Limitações do estudo}

Segundo Vergara (2000), todo método tem possibilidades e limitações e antecipá-los é deve do autor.

A pesquisa apresentou limitações oriundas da forma escolhida para a coleta de dados e, consequentemente, tratamento desses. Como exemplos dessa dificuldade que limitaram o método destacam-se essas: A pesquisa diz respeito apenas à opinião das mulheres empreendedoras sobre o preconceito e principais dificuldades no processo de empreender; a impossibilidade de entrevistar todas as mulheres empreendedoras do estado do Rio de Janeiro; a falta de experiência do entrevistador bem como o depoimento do entrevistado não corresponder à realidade devido a vergonha ou constrangimento de assumir já ter sido vitima de preconceito. 


\section{Apresentação e análise dos resultados}

Este capítulo, organizado em três seções, apresenta e discute os principais resultados alcançados com a pesquisa de campo.

\subsection{Descrição do perfil dos entrevistados}

As entrevistas foram realizadas com 16 mulheres empreendedoras do estado do Rio de Janeiro. Desse total, três (3) moram na cidade de Cabo Frio e 13 na cidade do Rio de Janeiro. A tabela 7 apresenta um resumo das principais características da amostra:

Tabela 7: Informações gerais da amostra

\begin{tabular}{|l|l|l|l|l|l|}
\hline \multicolumn{7}{|c|}{ Informações gerais da amostra } \\
\hline & Idade & Estado Civil & Filhos & Tipo de negócio & Duração do negócio \\
\hline Empreendedora 1 & 59 & Casada & Sim & Padaria & 18 anos \\
\hline Empreendedora 2 & 46 & Casada & Sim & Eventos & 4 anos \\
\hline Empreendedora 3 & 44 & Casada & Sim & Consultoria & 7 anos \\
\hline Empreendedora 4 & 45 & Divorciada & Sim & Tecnologia & 11 anos \\
\hline Empreendedora 5 & 36 & União Estável & Não & Consultoria & 8 anos \\
\hline Empreendedora 6 & 48 & Casada & Não & Consultoria & 6 anos \\
\hline Empreendedora 7 & 27 & Casada & Não & Curso & 1 ano e 6 meses \\
\hline Empreendedora 8 & 28 & Casada & Sim & Consultoria & 4 anos \\
\hline Empreendedora 9 & 32 & União Estável & Não & Confeitaria & 4 anos \\
\hline Empreendedora 10 & 37 & Solteira & Não & Consultoria & 8 anos \\
\hline Empreendedora 11 & 24 & Solteira & Não & ONG & 2 anos \\
\hline Empreendedora 12 & 52 & Casada & Sim & Lanchonetes & 22 anos \\
\hline Empreendedora 13 & 44 & Casada & Sim & Consultoria & 12 anos \\
\hline Empreendedora 14 & 26 & Solteira & Não & Consultoria & 2 anos \\
\hline Empreendedora 15 & 27 & União Estável & Não & Lan House & 5 anos \\
\hline Empreendedora 16 & 36 & Casada & Sim & Confeitaria & 45 dias \\
\hline
\end{tabular}

Fonte: Próprio autor (2016)

Cinco (5) das 16 entrevistadas, ou seja, 31\% possuem idade entre 44 e 49 anos. Quatro (4), ou seja, 25\% do total possuem de 26 a 31 anos e outras quatro (4), 25\% do total, estão na faixa etária entre 32 e 37 anos. Apenas uma (1) possui entre 20 a 25 anos, uma (1) entre 50 a 55 anos e outra tem mais de 55 anos. O gráfico 9 ilustra essas informações: 


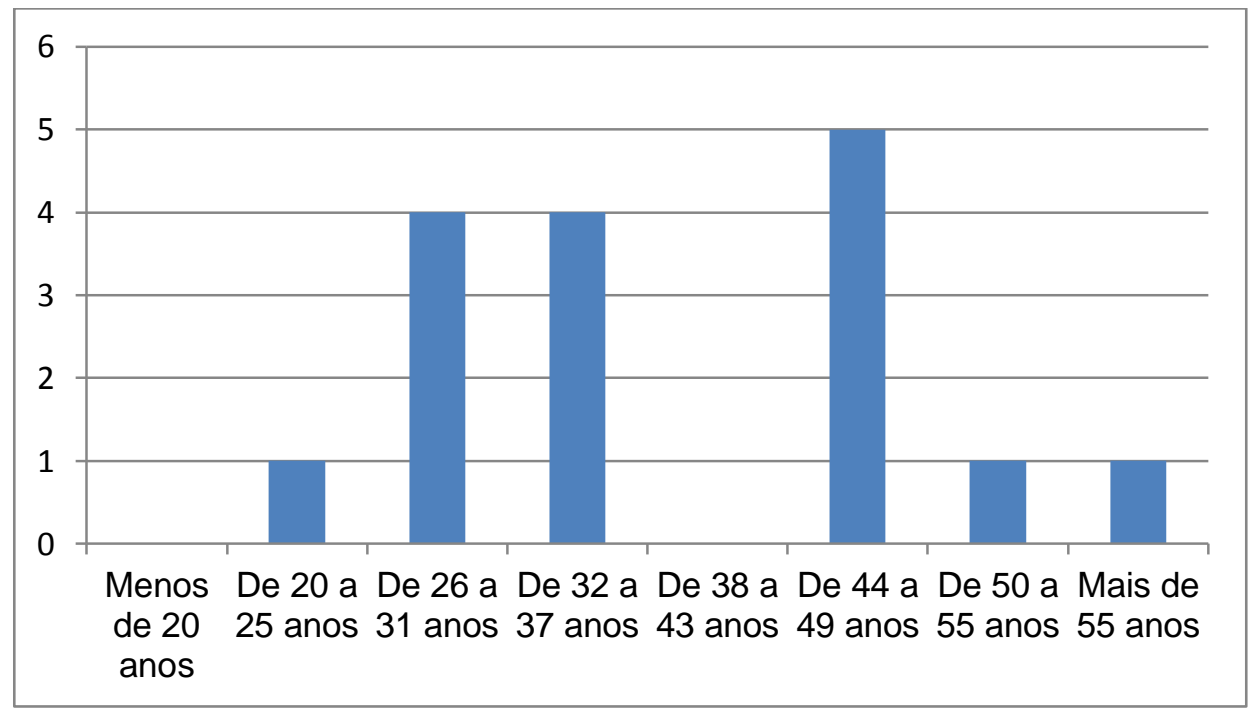

Gráfico 9: Idade das entrevistadas

Fonte: Próprio autor (2016)

A maioria das entrevistadas (56\%), ou seja, nove (9), são casadas. Três (3) estão em uma união estável, três (3) são solteiras e uma (1) é divorciada. Segundo dados da GEM (2015) a maioria dos empreendedores são casados e a amostra também do estudo ilustrou isso. As informações detalhadas seguem no gráfico 10 .

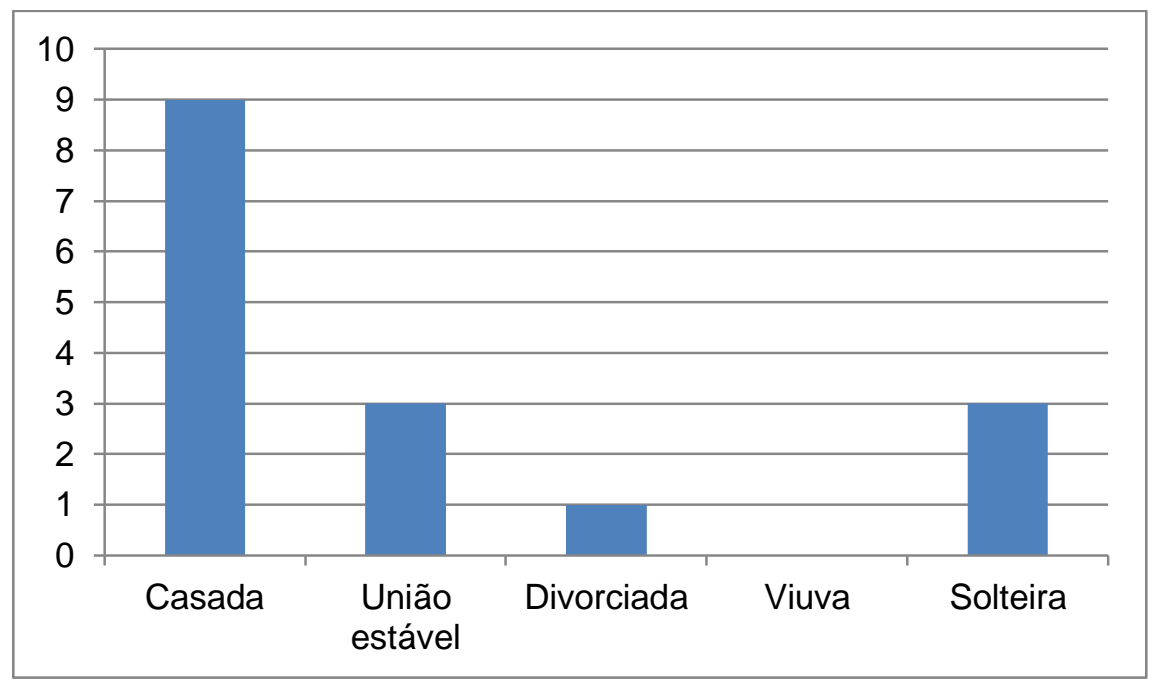

Gráfico 10: Estado civil das entrevistadas Fonte: Próprio autor (2016)

A metade das entrevistadas, ou $50 \%$, não possui filhos enquanto a outra metade possui de 1 a 2 filhos. O gráfico 11 detalha essa informação. 


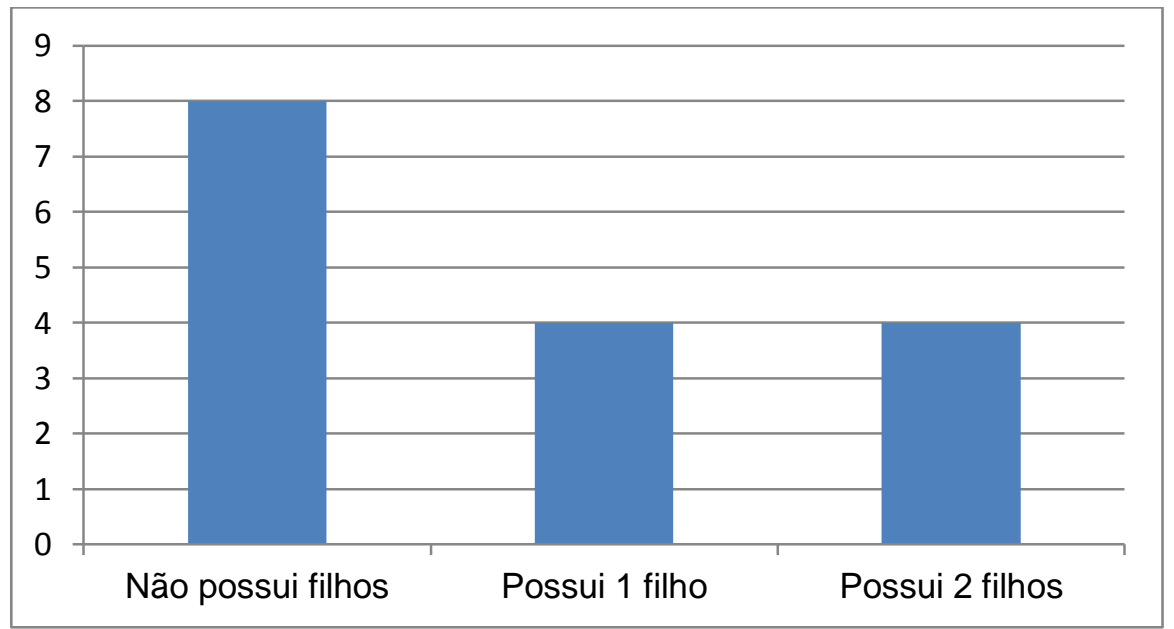

Gráfico 11: Número de filhos das entrevistadas Fonte: Próprio autor (2016)

As empreendedoras preocupam-se com os estudos. A maioria das entrevistadas, cinco (5), ou seja, 31\% da amostra possui o ensino superior completo. Quatro (4), ou 25\%, têm ensino superior incompleto e outras quatro (4) são mestres. Duas (2) possuem pósgraduação e apenas uma (1) possui ensino fundamental incompleto. Nenhuma das entrevistadas possui doutorado. As entrevistadas demonstraram que o conhecimento é importante para elas e que valorizam a cultura do estudo e trabalho para melhorarem de vida. O investimento delas na sua educação, de acordo com essa amostra, é coerente com o estudo de Mussak (2004), mostrando que as mulheres estão se preparando e investindo mais na sua educação, qualificando-se para o gerenciamento do negócio. O gráfico 12 mostra isso:

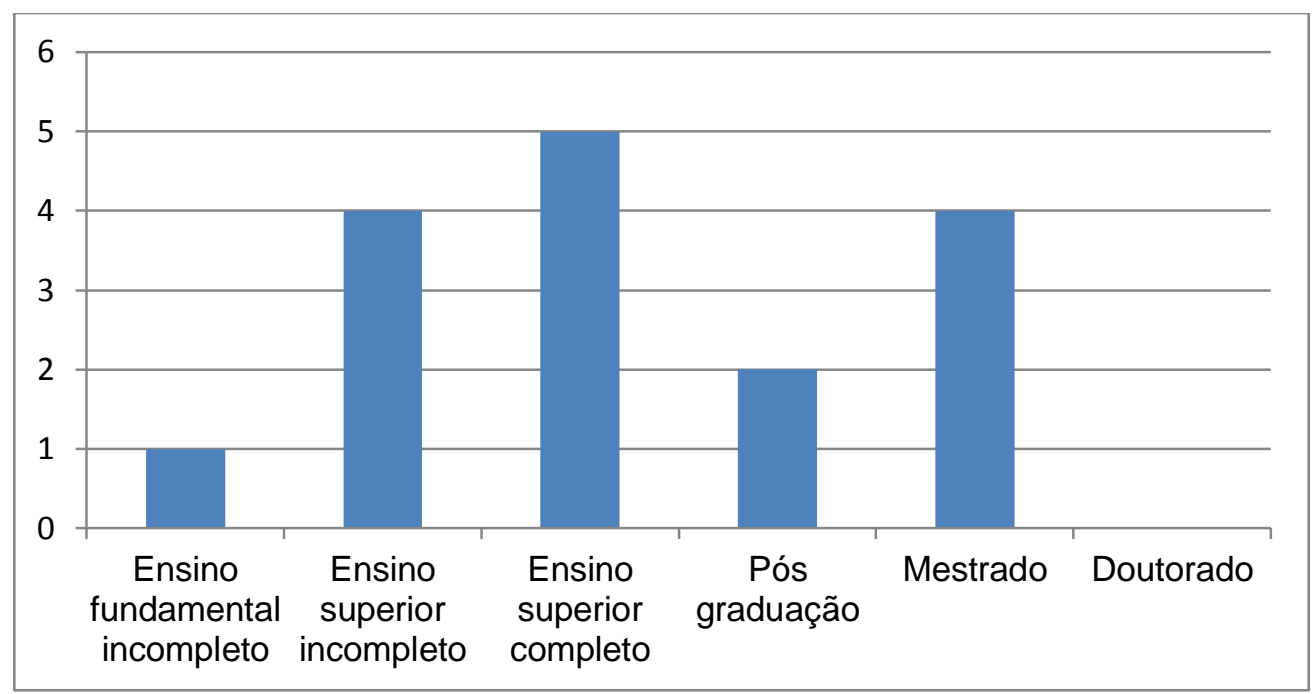

Gráfico 12: Grau de escolaridade das entrevistadas Fonte: Próprio autor (2016)

Para medir a renda dessas empreendedoras foi utilizado como referência o salário mínimo atual de 2016 que é $\mathrm{R} \$ 880,00$. A maioria, ou seja, seis (6) das entrevistadas, ou $37,5 \%$, recebe mais de 9 salários mínimos de renda mensal seguido por quatro (4) 
empreendedoras ou 25\% delas com rendimento mensal maior que 3 e até 6 salários mínimos, uma (1) com renda até 3 salários mínimos e uma (1) com renda maior que 6 até 9 salários mínimos. Pela amostra do estudo, a média de rendimento mensal das entrevistadas é de nove salários mínimos, o que é superior aos dados do SEBRAE (2015) que diz que o rendimento médio mensal da mulher empreendedora é em média $R \$ 1.464,00$ correspondendo a até dois salários mínimos. O gráfico 13 a seguir ilustra esse rendimento:

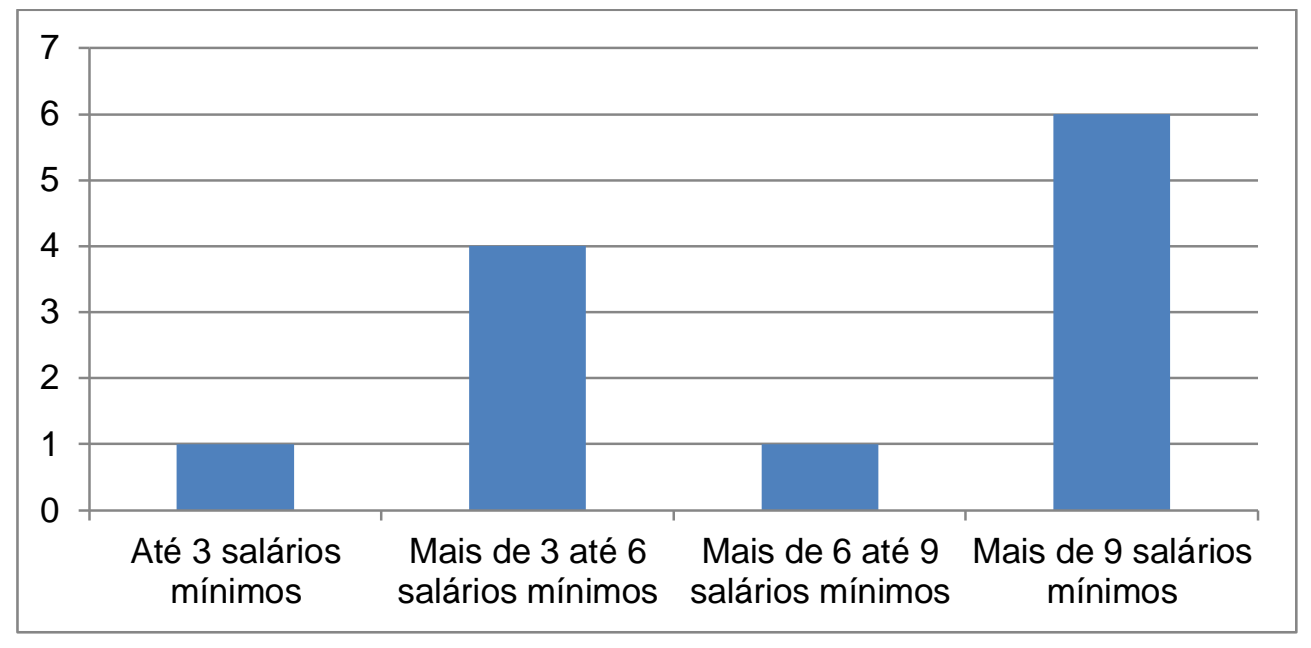

Gráfico 13: Rendimento médio mensal das entrevistadas Fonte: Próprio autor (2016)

O tópico a seguir abordará as respostas das empreendedoras mais diretamente ligadas ao empreendimento.

\subsection{Opção por empreender: Detalhamento}

A fim de compreender melhor a atuação das mulheres empreendedoras que integraram a amostra desse estudo, foram feitas diversas perguntas, cujas respostas serão apresentadas na sequência.

Foi questionado se as entrevistadas empreendem por conta própria ou se são empregadoras. Dez (10) responderam que empreendem por conta própria enquanto apenas seis (6) responderam que são empregadoras. Ou seja, 63\% delas trabalham por conta própria enquanto $37 \%$ trabalham empregando trabalhadores no regime de carteira assinada o que confirma os dados do SEBRAE (2015) que mostram que o tipo de empreendedorismo feminino dominante é por conta própria. Além disso, quatro (4) delas responderam que possuem mais de uma empresa. O gráfico 14 mostra essa proporção de empreendedoras por conta própria e empregadoras: 


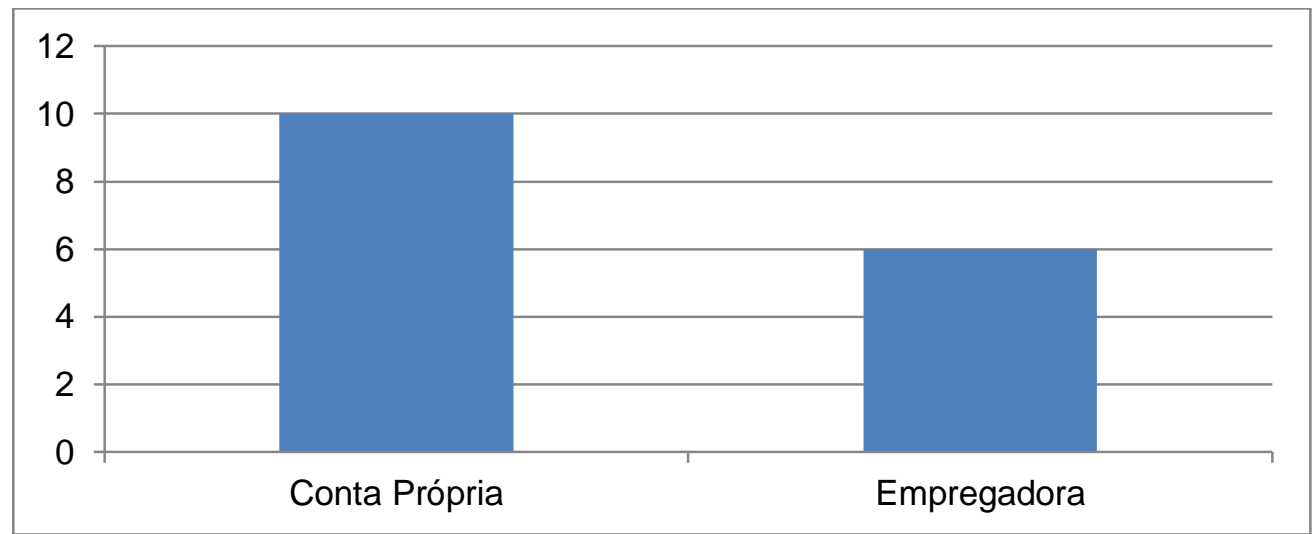

Gráfico 14: Empreendedoras por posição na ocupação do mercado de trabalho Fonte: Próprio autor (2016)

Sete (7) responderam que possuem sociedade com o marido e todas que possuem conjugue responderam que ele trabalha na empresa como seu sócio ou como empregado fora da empresa. A maioria das que são empregadoras possuem até 5 empregados com apenas uma (1) relatando que possui mais de 30 empregados.

Também foi perguntado qual idade tinham quando decidiram empreender: cinco (5) delas ou $31,25 \%$, responderam ter de 20 a 24 anos; três (3) ou 18,75\%, responderam ter entre 25 a 29 anos; três (3) de 30 a 34 anos; três (3) possuem mais de 40 anos e apenas duas (2) ou 12,5\%, possuem entre 35 a 39 anos. A média de idade das mulheres entrevistadas quando decidiram empreender é de 30 anos. Morais (2015) afirma que a faixa de idade em que uma mulher empreende é entre 35 e 40 anos, o que foi um pouco diferente ao identificado na amostra desse estudo. O gráfico 15 a seguir mostra a faixa de idade quando a decisão de empreender foi tomada:

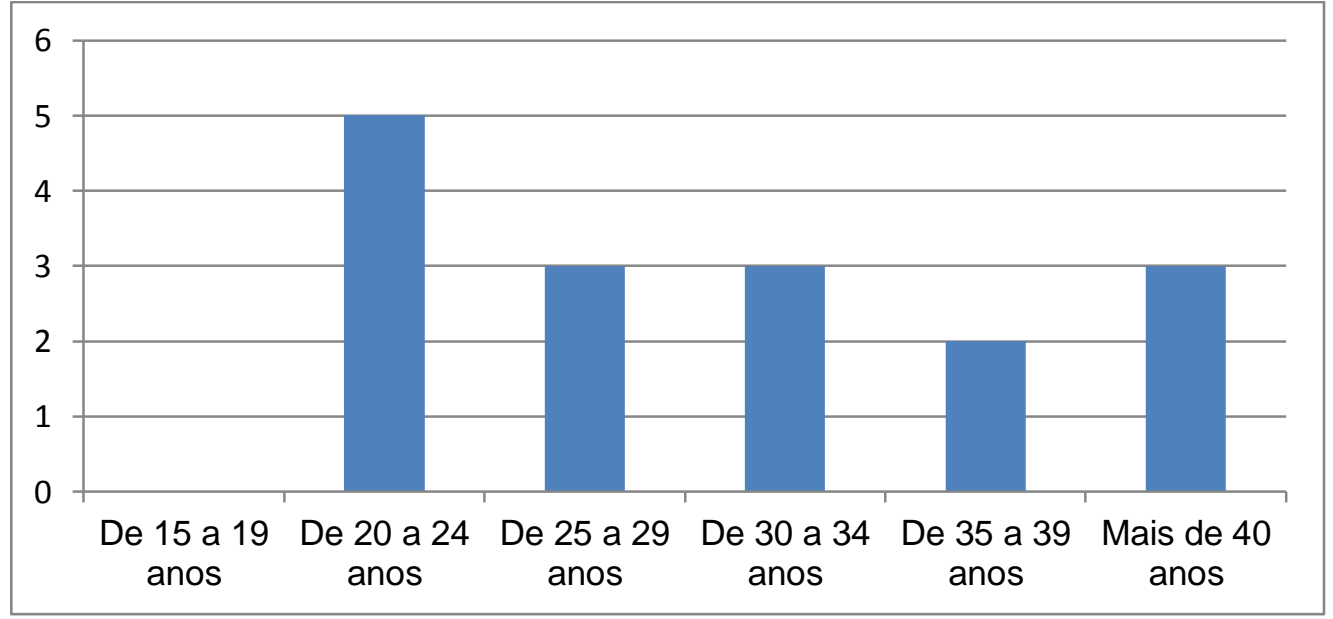

Gráfico 15: Idade referente à decisão de empreender Fonte: Próprio autor (2016)

Sobre o tempo de existência do empreendimento, a maioria relatou possuir seu negócio há mais de quatro (4) anos e nenhuma herdou a empresa da família. A média de tempo de existência das empresas das 16 entrevistadas é de sete (7) anos. Pode se dizer que a taxa de sobrevivência das empresas, comparada aos dados do IBGE (2013) que 
informa que metade das empresas fecha as portas no Brasil após quatro anos, é alta. O achado da pesquisa pode ser compreendido segundo Dornelas (2013), que diz que as empresas administradas por mulheres sobrevivem mais tempo no mercado se comparadas a empresas que possuem apenas homens no corpo diretivo.

As entrevistadas, quando questionadas sobre a motivação para empreender, apontaram inúmeras razões. As respostas mais mencionadas foram: três (3) flexibilidade, três (3) autonomia e três (3) independência. A tabela 8 detalha as respostas dadas. $O$ estudo do Machado et al (2003) aponta que as mulheres criam novas empresas por diferentes razões, como, por exemplo: o desejo de independência, oportunidade de mercado, dificuldade em ascender profissionalmente em outras empresas e por necessidade, o que foram, de certa forma, aspectos presentes do discurso da amostra estudada.

O Relatório do GEM (2015) apontou que as mulheres têm empreendido mais por necessidade, porém essa amostra apresentou um resultado diferente, visto que apenas uma empreendedora foi motivada pela necessidade.

De acordo com as entrevistas um dos motivos de empreender foi trabalhar com o que se identificam. Elas demonstraram que gostam de trabalhar como empreendedoras e que trabalham naquilo que gostam. Isso é dito por Hisrich (2004) quando destaca que as empreendedoras buscam realização pessoal e não apenas profissional.

Tabela 8: Número de respostas sobre as motivações para empreender

\begin{tabular}{|l|l|}
\hline \multicolumn{2}{|c|}{ Razões para empreender } \\
\hline 3 & Flexibilidade \\
\hline 3 & Autonomia \\
\hline 3 & Independência \\
\hline 2 & Sonho \\
\hline 2 & Crescimento profissional \\
\hline 2 & Trabalhar com o que gosta \\
\hline 2 & Algo que desse significado para ela \\
\hline 1 & Oportunidade \\
\hline 1 & Melhorar de vida \\
\hline 1 & Satisfação profissional \\
\hline 1 & Necessidade \\
\hline 1 & Vontade de ter o próprio negócio \\
\hline 1 & Formação educacional \\
\hline 1 & Influência familiar \\
\hline
\end{tabular}

Fonte: Próprio autor (2016) 
A amostra indicou que o setor predominante onde estão inseridas as empreendedoras é o de serviços. Das 16 entrevistadas, 12 ou $75 \%$ delas trabalham nesse setor, o que confirma o estudo apontado por Morais (2015) que diz que as mulheres têm tendência para áreas ligadas à prestação de serviços e os dados do SEBRAE (2015) que também mostram a prevalência das mulheres no setor de serviços. Apenas duas (2) responderam que atuam no setor de comércio e duas (2) no setor da indústria. O gráfico 16 apresenta essas informações:

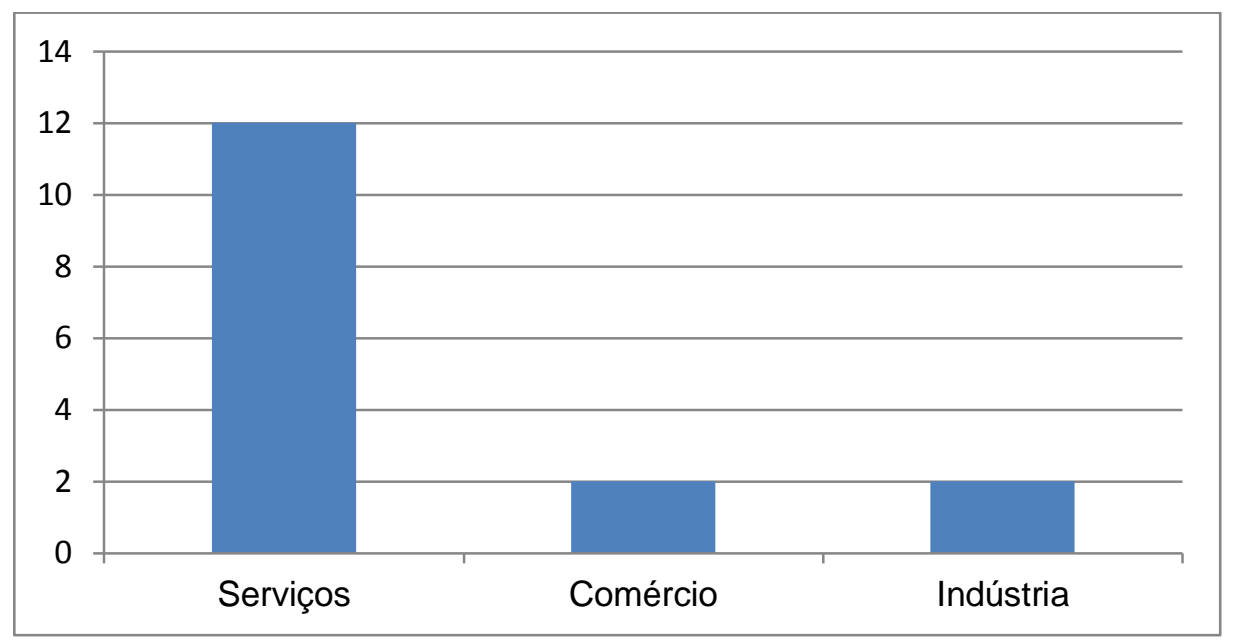

Gráfico 16: Setor de atuação das empreendedoras entrevistadas Fonte: Próprio autor (2016)

Como mostrado na tabela 6 o tipo de empreendimento predominante entre essas empreendedoras com sete (7) delas é a consultoria que está inserida no setor de serviços. As demais inseridas nesse setor empreendem com tecnologia, eventos, curso, ONG e Lan House. No setor de comércio e indústria estão às outras empreendedoras que empreendem com padaria, lanchonetes e confeitaria.

As empreendedoras também foram questionadas sobre a carga diária de dedicação à(s) empresa(s). A maioria, com nove (9) respondentes, disse que é de 9 horas ou mais. Quatro (4) disseram que dedicam até 6 horas e três (3) dedicam de 7 a 8 horas. A média das entrevistadas corresponde a 8 horas e meia de dedicação. O gráfico 17 ilustra isso: 


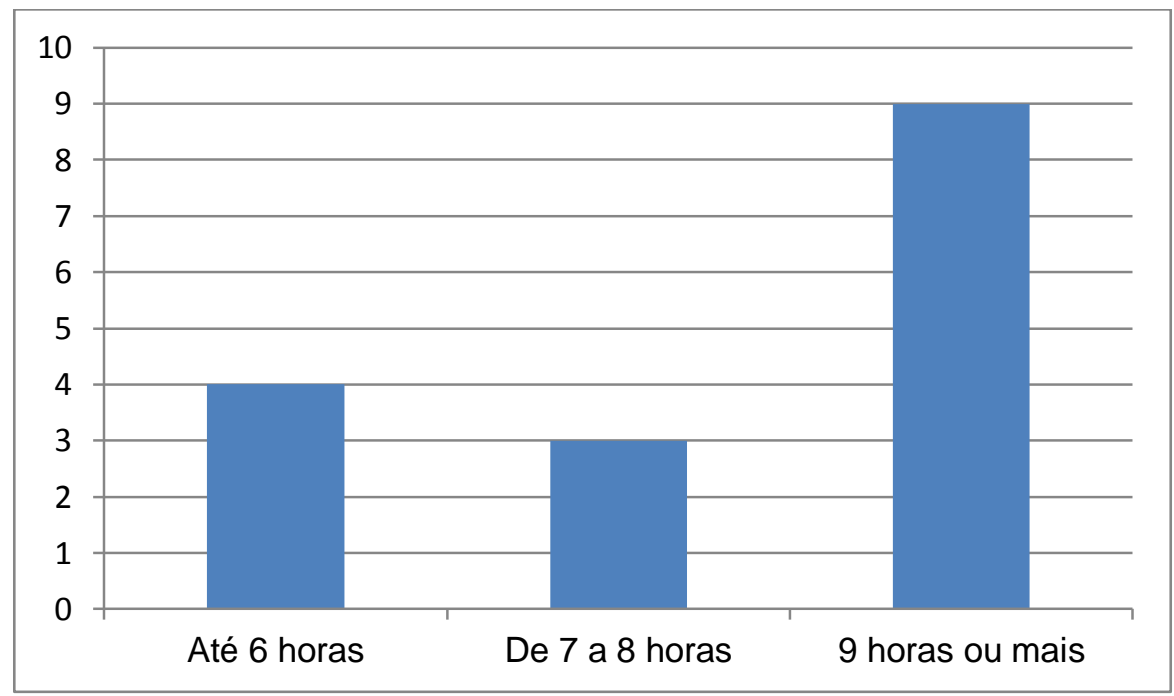

Gráfico 17: Carga diária de dedicação à vida empreendedora Fonte: Próprio autor (2016)

As entrevistadas responderam também se a(s) empresa(s) eram seu trabalho único ou se possuíam outra fonte de renda. Das 16 entrevistadas, nove (9) disseram ser sua única fonte de renda, ou seja, trabalho único, enquanto as outras sete (7) relataram que possuem outra fonte de renda além do empreendedorismo. Perguntadas sobre quantas rendas existem em sua casa, a maioria, ou seja, dez (10) delas responderam duas (2) - dela e do marido - e três (3) responderam que existem três (3) rendas sendo que dessas três (3) rendas uma respondeu que é dela, do marido e da enteada e as outras (2) empreendedoras responderam que é dela, da mãe e do pai. Apenas duas (2) responderam haver apenas a sua renda. Sobre o percentual dos custos fixos mensais da família que elas arcam, a maioria, ou seja, oito (8), respondeu $50 \%$.

Questionadas sobre trabalhar anteriormente em empresas com carteira assinada, 14 delas ou $87,5 \%$ disseram que já trabalharam enquanto apenas duas (2) responderam que não trabalharam. Dentre as que não trabalharam, uma (1) não trabalhou porque é muito jovem e teve apenas um estágio e a outra optou, por escolha própria, não trabalhar com carteira assinada. O gráfico 18 apresenta essas informações: 


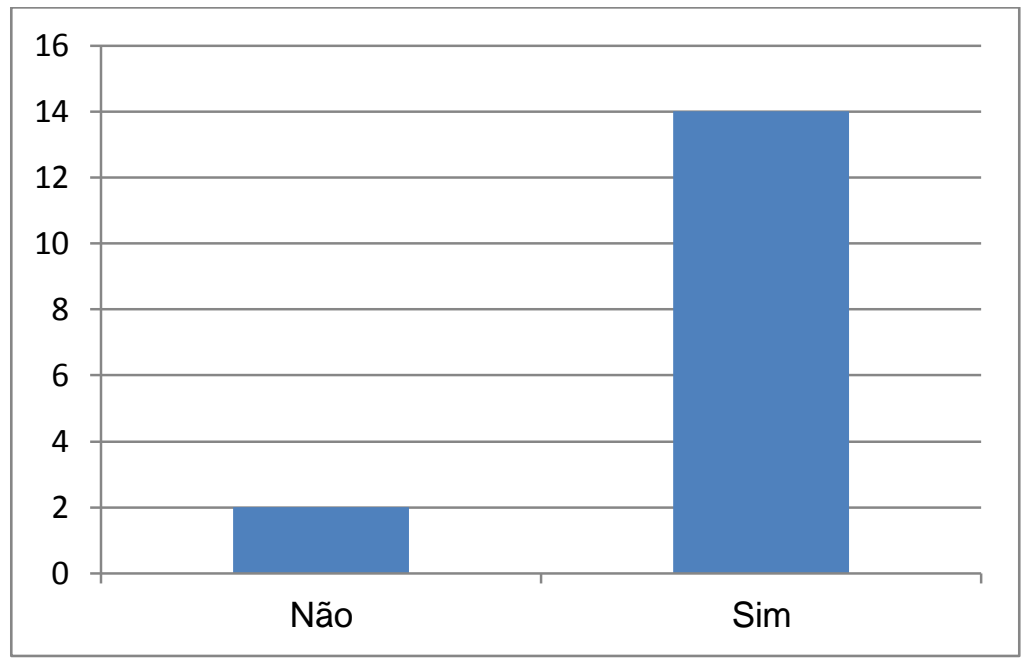

Gráfico 18: Trabalhou anteriormente com carteira assinada em empresas Fonte: Próprio autor (2016)

Sobre a duração do trabalho com carteira assinada, das 14 que responderam sim, a maioria com dez (10) trabalhou mais de 6 anos enquanto que duas (2) delas responderam até 2 anos, uma (1) respondeu de 3 a 4 anos e uma (1) de 5 a 6 anos como mostra o gráfico 19.

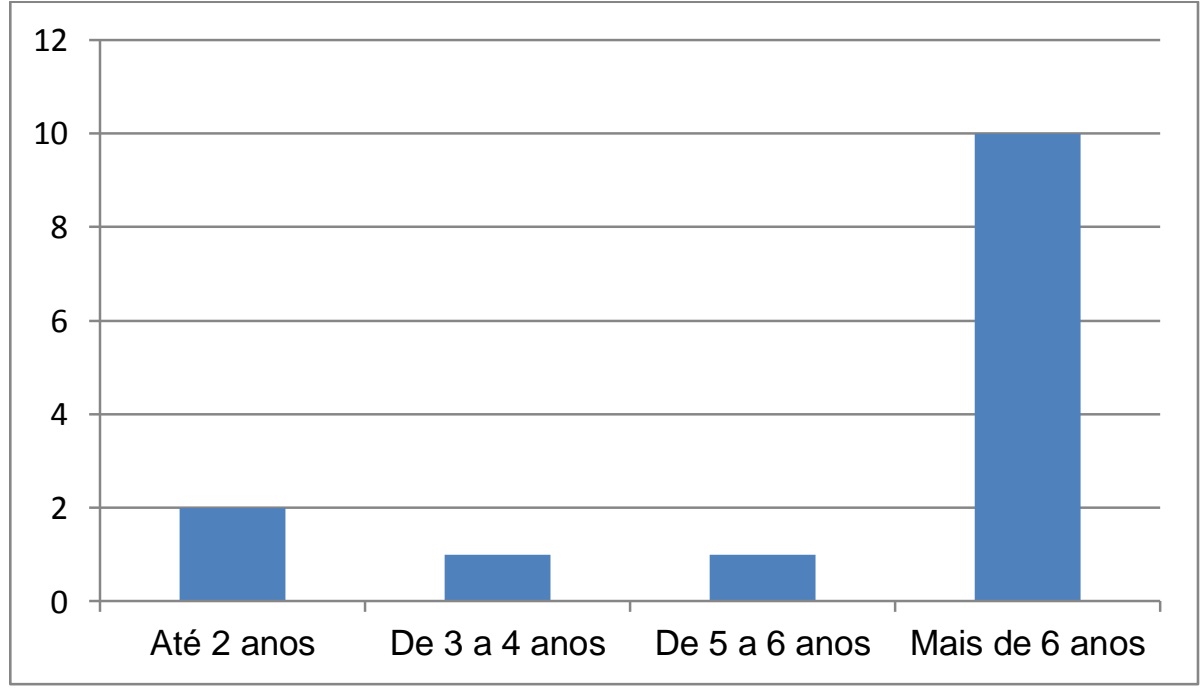

Gráfico 19: Duração de tempo trabalhando com carteira assinada Fonte: Próprio autor (2016)

O tópico a seguir apresenta os resultados mais específicos relacionados às dificuldades relatadas pelas empreendedoras.

\subsection{Dificuldades relatadas}

No decorrer das entrevistas foi perguntado às entrevistadas se percebiam diferença de tratamento por serem mulheres. A amostra apresentou um equilíbrio nessa percepção, pois oito (8), ou $50 \%$, relatam que não perceberam nenhum tratamento diferenciado - nem para melhor, nem para pior - enquanto que a outra metade declarou que percebe diferença de tratamento para pior. Dentre as que responderam que sentem diferença de tratamento, 
quatro (4) delas foram as que tem consultoria e sentem principalmente quando vão tratar de algum tema financeiro com clientes ou prestadores de serviço, principalmente quando iniciaram o negócio e ainda não tiveram oportunidade de mostrar seu potencial de trabalho, possuem pouca experiência por serem novas e pelo gênero. A empreendedora responsável pela empresa de eventos relata que existem atividades que as pessoas (clientes do serviço) associam com o sexo masculino e que sente diferença de tratamento quando tem que lidar com o cliente sobre algumas dessas atividades. A empreendedora que empreende com Lan House sente também diferença principalmente pela área que empreende ter mais homens que mulheres. Os dados são apresentados no gráfico a seguir:

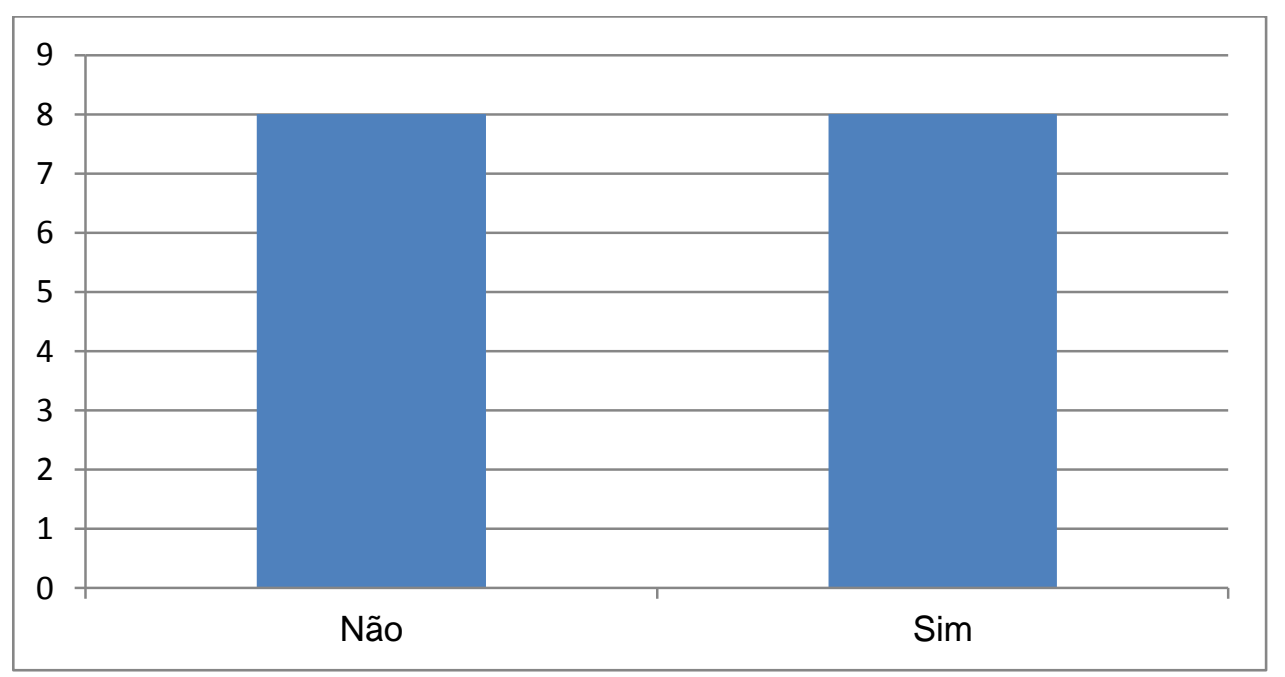

Gráfico 20: Percepção de diferença no tratamento por ser mulher e dona do próprio negócio Fonte: Próprio autor (2016)

Elas também foram questionadas se já sentiram ou sentem dificuldade de empreender por conta da idade. Mais da metade delas, com nove (9) ou 56,25\% respondentes, disseram que não sentem dificuldade e as outras sete (7) ou $43,75 \%$ disseram que sentem. Das que disseram que sentem cinco (5) delas falaram que foi devido a idade por serem jovens. As demais falaram do desgaste natural da idade por isso tem dificuldade de empreender:

"Hoje não, mas no início sim, tive que mostrar muito resultado para conquistar o respeito das pessoas." (Empreendedora 5, 36 anos)

"Senti preconceito com relação a minha idade por ser muito nova." (Empreendedora 8, 28 anos)

"No início senti por ser bastante nova e as pessoas olharem e pensarem "não tem experiência." (Empreendedora 10, 37 anos)

A amostra indica que, apesar de muitas delas não sentirem dificuldade, algumas sentiram e é o que Alperstedt, Ferreira e Serafim (2014) explicam dizendo que existe dificuldade das mulheres de empreender por questão da idade. São apresentados esses dados no gráfico 21 : 


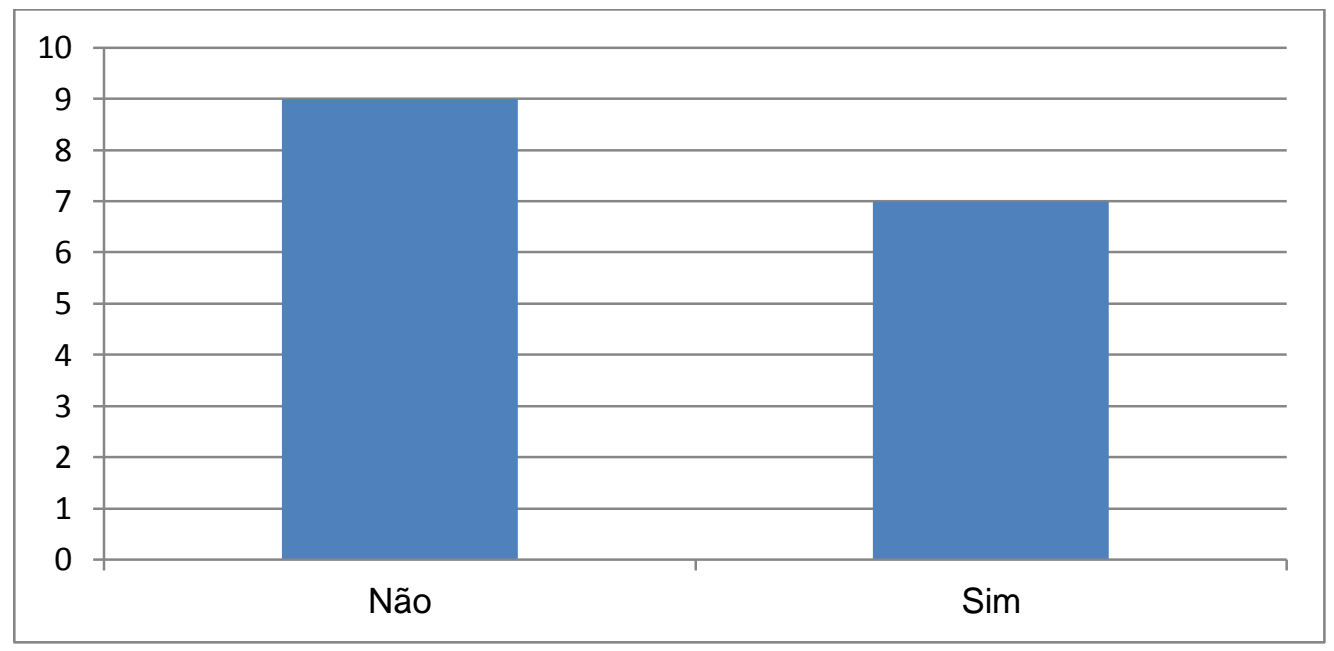

Gráfico 21: Sentiram ou sentem dificuldade de empreender por conta da idade Fonte: Próprio autor (2016)

Quando questionadas se já tinham sofrido preconceito no mundo dos negócios, a maioria com dez (10) ou 62,5\% respondeu que sim, enquanto seis (6) ou $37,5 \%$ delas disseram que não. Os relatos da maior parte das respondentes da pesquisa confirmam o que foi dito por Andreoli e Borges (2007) que o ambiente empresarial possui caráter machista e ambiente propício à discriminação, o que é uma dificuldade para as mulheres. $O$ gráfico 22 apresenta essa informação.

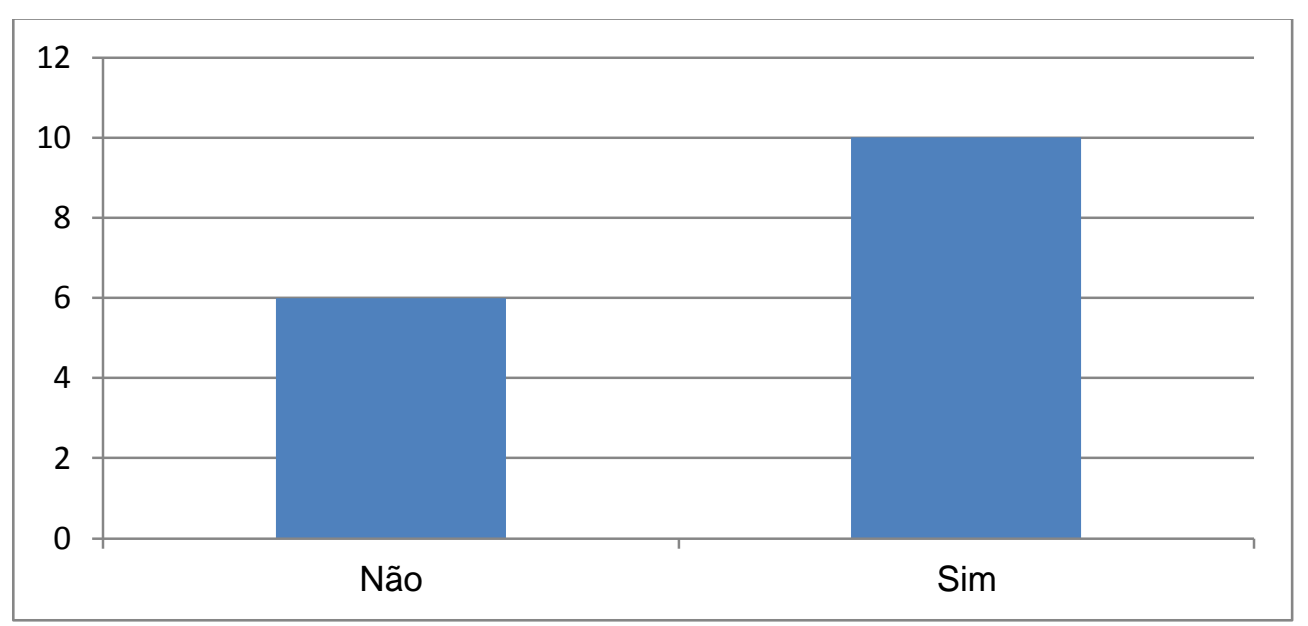

Gráfico 22: Sofreram preconceito no mundo dos negócios Fonte: Próprio autor (2016)

Das que responderam sim uma foi bem enfática e diz que trabalha em uma área que tem muitos homens e que isso acaba prejudicando a relação:

"Já sofri preconceito e quando vou prestar consultoria e a empresa tem muitos homens eles se sentem muito incomodados. Sinto tanto com homens mais novos quanto mais velhos. É impressionante!" (Empreendedora 13, 44 anos)

Foi perguntado também a elas se poderiam citar e explicar uma situação em que foram vitimas de preconceito e o porquê acham que isso aconteceu. Uma delas relatou preconceito sofrido por parte de outras mulheres: 
Quando eu fundei um projeto chamado "Empreendedorismo Rosa" (não faço mais parte hoje, saí em 2013) muita gente criticava achando que era um movimento de "mulherzinha". O que não tinha nenhuma ligação, o preconceito estava pelo fato de ter o nome ROSA embutido. Durante o tempo que fiquei nesse projeto tivemos críticas inclusive de mulheres. Nesse momento vi como que a questão de gênero é ainda algo tão limitante, inclusive na cabeça das mulheres. O que me mostrou que para a mulher ser respeita e ocupar o seu lugar no mundo ela não precisa gritar, é só ir lá e fazer. O espaço é construído através de um dia de cada vez, com muita garra, trabalho e conhecimento aplicado. (Empreendedora 5, 36 anos)

Ao final da fala, ela relata que a construção do respeito ocorreu aos poucos o que contribui para a compreensão de Cramer et al (2012) que dizem que as mulheres necessitam provar continuamente que são capazes de administrar seus negócios para conseguirem conquistar seus espaços como empreendedoras.

Uma empreendedora relatou que sofreu preconceito quando foi negociar e que a situação foi diferente quando pediu ao pai dela para fazer o negócio:

Quando organizei uma viagem e fui negociar um barco para o passeio o rapaz do barco virou e perguntou: "O que essa garota quer?". No dia seguinte o meu pai foi lá junto comigo e negociou sem problema e o rapaz já deu outro valor e respeito a ele diferente do que fez comigo. (Empreendedora 14, 26 anos)

O estudo do Botelho et al (2008) que diz que é um desafio para as empreendedoras administrarem seus negócios num espaço predominantemente masculino é coerente com o que uma das empreendedoras entrevistas relatou. Ela diz que sofreu preconceito por conta do ambiente de trabalho onde foi prestar consultoria ter muitos homens:

Em uma reunião na casa $X$ eu estava dando ordem no andamento da obra e os engenheiros (prestadores de serviço) disseram que eu não sabia o que estava falando mas eu já tinha me preparado pra esse ambiente e tinha pedido auxilio ao meu marido e um engenheiro amigo meu. Eles (os engenheiros prestadores de serviço) perguntaram: "O que essa menina esta fazendo aqui? Esta me dando ordem por quê?". Eu estava lidando com homens, engenheiros de 50 e poucos anos. (Empreendedora 13, 44 anos)

As entrevistadas foram questionadas sobre a principal fonte de recursos para abrir a empresa. Das 16 entrevistadas 12 ou 75\%, investiram dinheiro próprio em sua(s) empresa(s). Duas (2) responderam empréstimo familiar, uma (1) empréstimo bancário e apenas uma (1) não precisou de nenhum recurso, pois começou a empreender por meio de um blog no qual não precisa de investimento e que é gratuito. Os achados das entrevistas confirmam o estudo de Machado et al (2003) que dizem que a principal fonte de recurso para a mulher conseguir abrir sua própria empresa é proveniente de economias pessoais, empréstimos familiares ou de amigos, apesar de nenhuma entrevistada ter relatado empréstimo de amigos. Ao todo 14 ou $87,5 \%$ delas relataram ter utilizado recurso próprio e empréstimo familiar. O gráfico 23 mostra isso: 


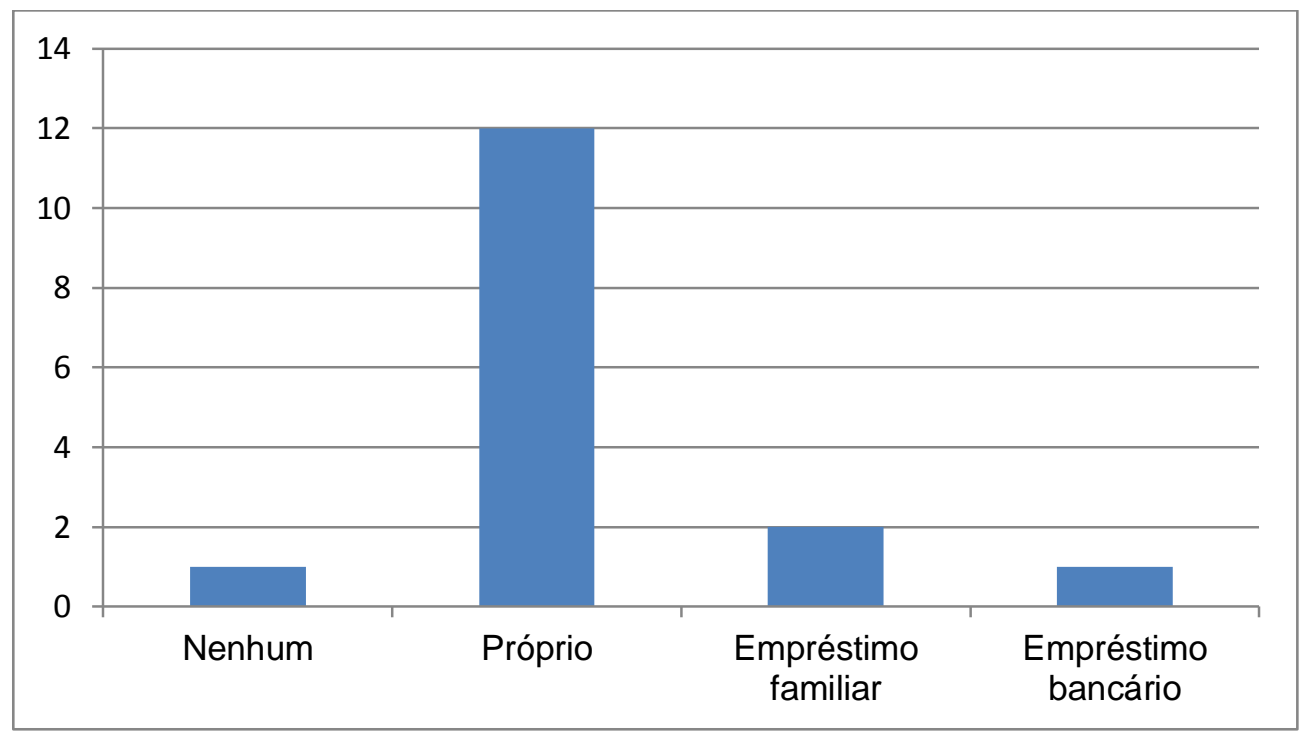

Gráfico 23: Recurso para abrir o negócio

Fonte: Próprio autor (2016)

A empreendedora que utilizou empréstimo bancário relata que teve que pedir empréstimo em nome do seu pai:

"Empreendedores iniciantes não tem suporte financeiro algum em nosso país. Meu empréstimo foi no nome do meu pai, que é militar e tem linhas de crédito acessíveis." (Empreendedora 7, 27 anos)

As mulheres foram questionadas sobre o percentual de tempo que dedicam a família e ao empreendimento. A maioria da amostra com oito (8) ou $50 \%$ das respondentes relatou que dedicam de $31 \%$ a $40 \%$ a família e sete (7) ou $43,75 \%$ delas de $61 \%$ a $70 \%$ ao empreendimento. Seis (6) delas dedicam até $30 \%$ de tempo a família e seis (6) de $51 \%$ a $60 \%$ ao empreendimento. Apenas uma relata dedicar mais de $70 \%$ ao empreendimento. Cramer et al (2012) dizem que a mulher necessita estar com a família porém, em função do negócio elas abrem mão do tempo destinado a convivência com a família e de suas tarefas de mãe e esposa para se dedicarem ao empreendimento. Pela amostra estudada percebese uma coerência com o estudo desses autores, pois há maior dedicação de tempo ao empreendimento do que a família. A seguir o gráfico 24 mostra essas respostas: 


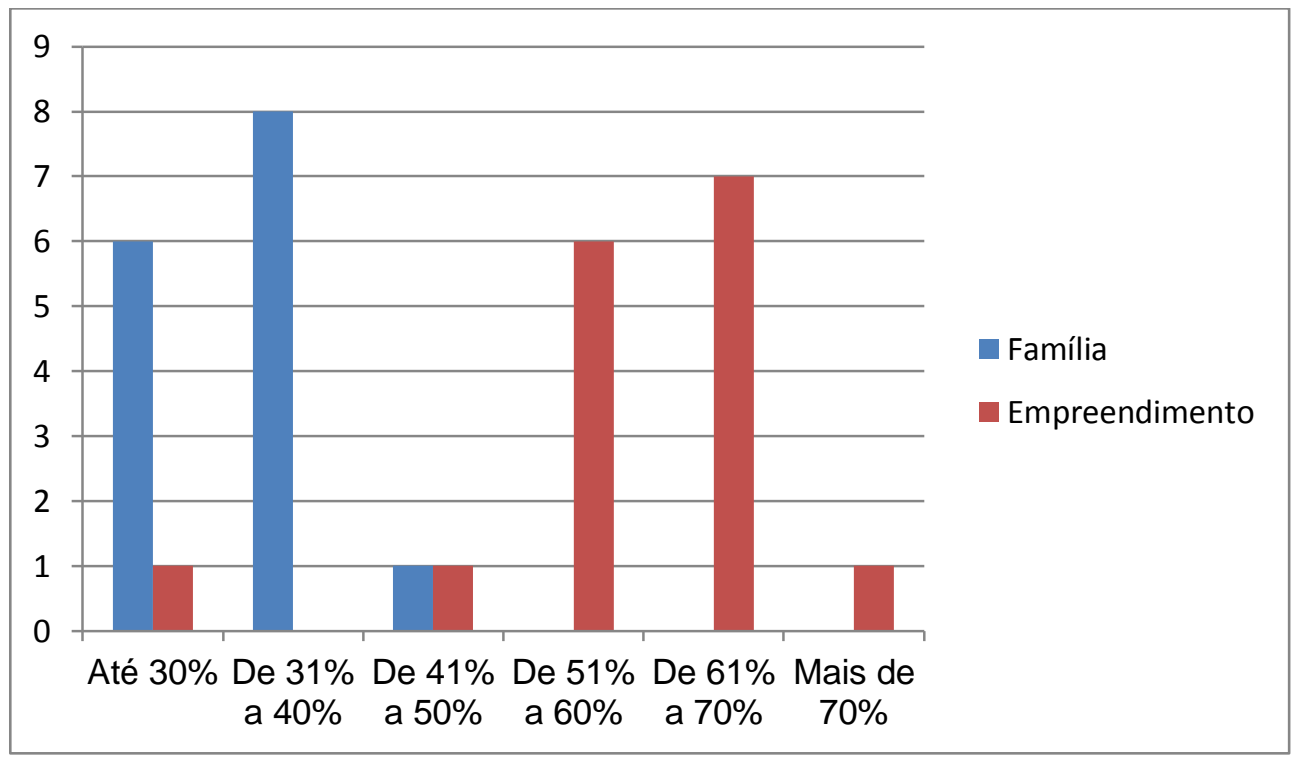

Gráfico 24: Percentual de tempo de dedicação à família e ao empreendimento Fonte: Próprio autor (2016)

GEM (2015) destaca que a percepção das pessoas com relação ao empreendedorismo é favorável e que os brasileiros tem uma visão positiva a respeito dos indivíduos envolvidos com negócios próprios. As entrevistadas foram questionadas se alguém da família já se opôs ao negócio e a maioria, ou seja, 11 das entrevistadas disseram que não tiveram oposição enquanto cinco (5) disseram que tiveram oposição o que é coerente com o relatório do GEM. Os dados do gráfico 25 mostram isso.

Das empreendedoras que tiveram oposição, uma conta que, por empreender no terceiro setor, teve que enfrentar problemas com a família. O relato dessa empreendedora segue abaixo mostrando essa oposição familiar:

"Pais e familiares em geral se opuseram contra, pois queriam que eu trabalhasse em um emprego rentável para o meu potencial já que eu tinha cursos de língua que já era formada. Eles não aceitaram bem isso no início mas hoje já tenho apoio da minha família. " (Empreendedora 11, 24 anos)

Outra empreendedora diz que teve problema familiar por causa do seu empreendimento e relata a preocupação da família com a renda do seu negócio:

"Família inteira se opôs. A minha avó até hoje não entende o meu o trabalho. Eles acham que eu podia ter seguido na carreira de direito e ter meu próprio escritório que seria mais garantido a fonte de renda." (Empreendedora 14, 26 anos) 


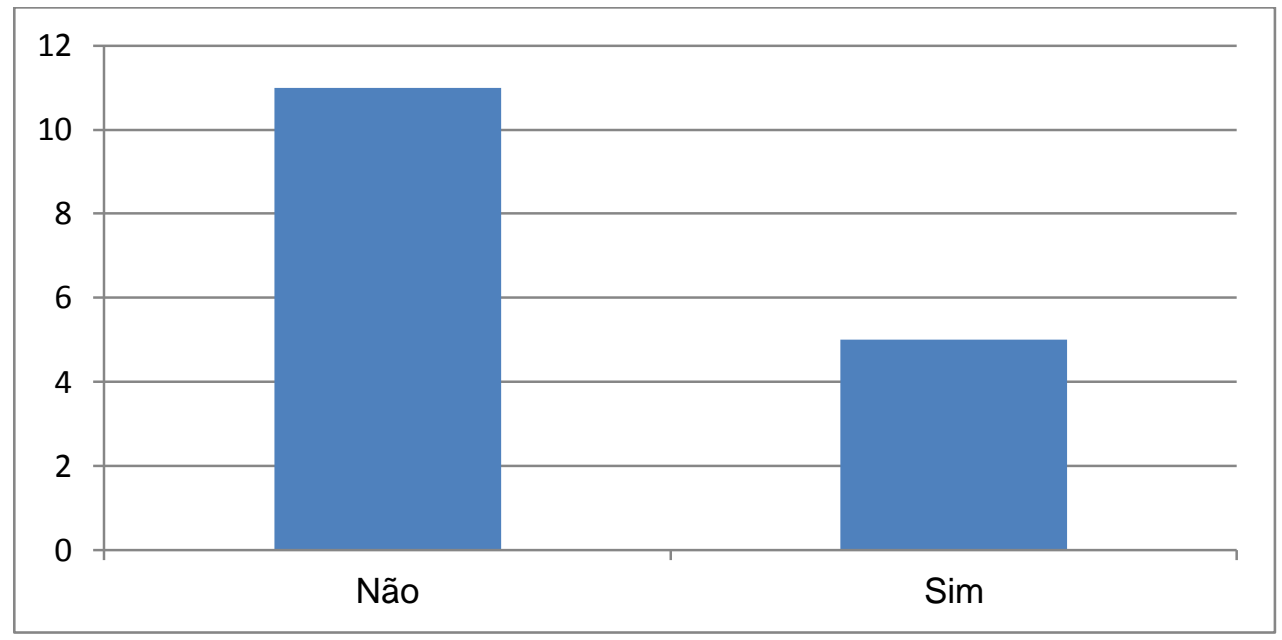

Gráfico 25: Oposição de alguém da família ao negócio Fonte: Próprio autor (2016)

Outra pergunta objetivou identificar a existência de pressão familiar por administrar o negócio e as respostas foram equilibradas. Oito (8) ou 50\% das entrevistadas sentem pressão enquanto que a outra metade das entrevistadas não. De certa forma, as afirmações de Buttner e Moore (1997) foram encontradas na pesquisa. Segundo os autores, a influência familiar como à pressão do marido e dos filhos é uma dificuldade que essas mulheres empreendedoras enfrentam ao administrarem seus negócios. O gráfico 26 mostra essa relação:

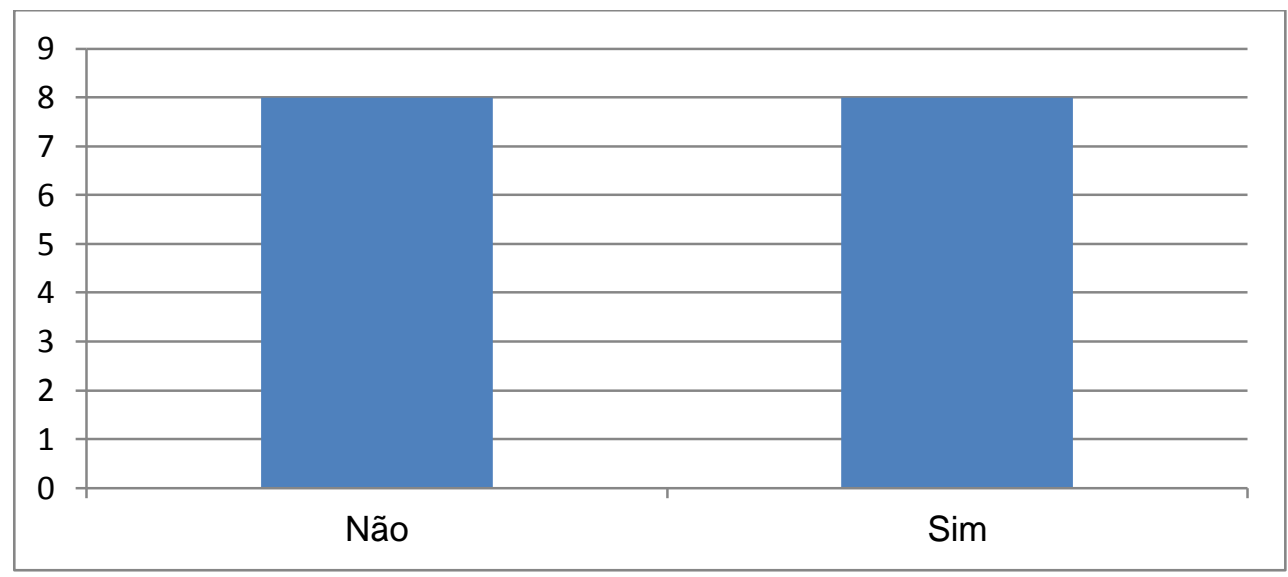

Gráfico 26: Pressão familiar por administrar o negócio Fonte: Próprio autor (2016)

Também foi perguntado se é difícil conciliar o trabalho com a família e a maioria das entrevistadas com dez (10) ou 62,5\% responderam sim enquanto as outras seis (6) ou $37,5 \%$ disseram que não. Das que responderam sim, oito (8) são casadas e/ou com filho(s), uma (1) está em uma união estável e apenas uma (1) é solteira e não possui filhos. Das seis (6) que responderam que não é difícil conciliar, duas (2) são solteiras e sem filhos. Outra desse grupo que respondeu não a pergunta é casada e sem filhos e diz que é porque é sócia do marido e é mais fácil para ela essa conciliação já que trabalha junto com ele. $A$ afirmação de Gomes (2004) que diz que a mulher tem dificuldade em conciliar trabalho e 
família é similar com os resultados obtidos nessa amostra, pois a maioria declara sentir dificuldade em conciliar trabalho-família. O Gráfico 27 apresenta essas informações.

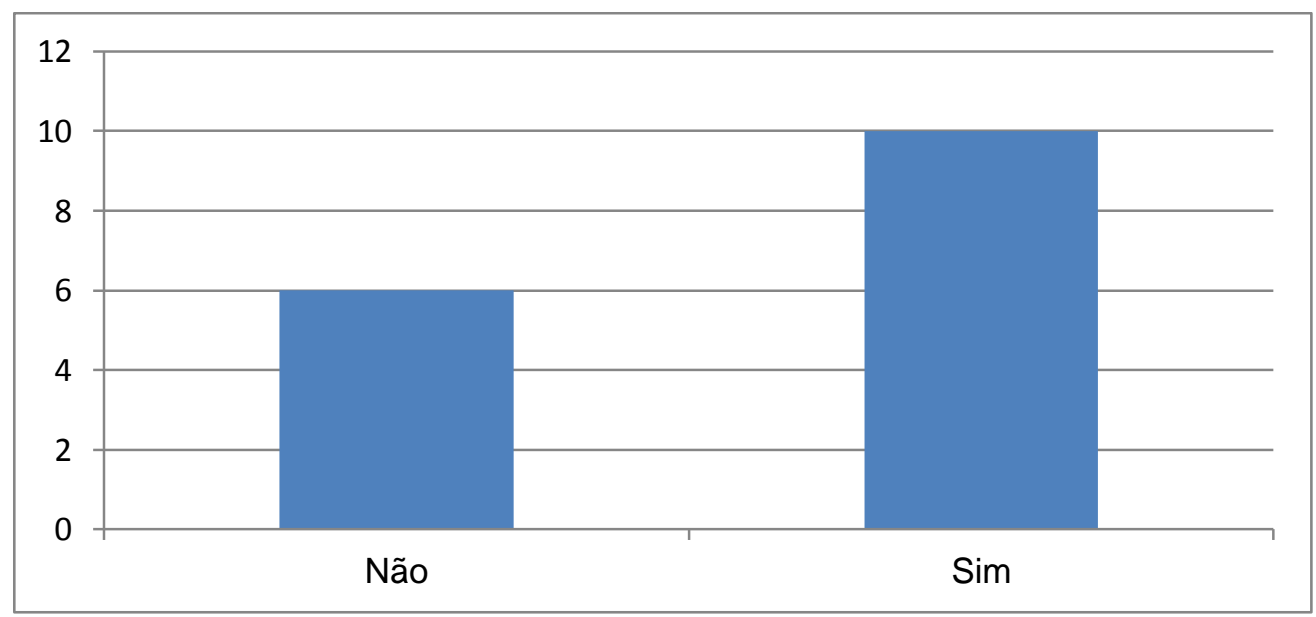

Gráfico 27: É difícil conciliar o trabalho com a família?

Fonte: Próprio autor (2016)

A maioria delas, 11 respondentes, relatou que ajuda nas tarefas domésticas quando chega do trabalho e apenas cinco (5) disseram que não, sendo que dessas cinco (5) que disseram que não, todas têm empregada. Das 12 mulheres que têm marido e/ou filhos, quando perguntadas se eles ajudam nas tarefas de casa, sete (7) delas responderam que ajudam enquanto cinco (5) responderam que não. Das cinco (5) que responderam que eles não ajudam, três (3) delas tem empregada enquanto duas (2) não tem e apenas elas que fazem as tarefas. Essas respostas são coerentes com o que Silva (2007) afirma sobre o estresse de lidar com trabalho empresarial e o cuidado da casa, pois quando chegam em casa ainda têm que lidar com as tarefas domésticas e a divisão desvantajosa dessas tarefas.

Foi perguntado também qual o maior desafio em ser uma mulher empreendedora. A administração do tempo foi o item mais citado, assim como os múltiplos papéis que assumem como empreendedoras, esposas, mães e donas de casa:

"Fazer inúmeras tarefas ao mesmo tempo como trabalhar e ser dona de casa e ainda ter tempo para se cuidar e tempo com a família." (Empreendedora 1, 59 anos)

"De esperar que o negócio cresça, o desafio de também querer ter um espaço para vida pessoal, administrar o tempo. " (Empreendedora 4, 45 anos)

"Organização de tempo e a incerteza no fluxo de renda." (Empreendedora 3, 44 anos)

Algumas declararam que ser respeitada é o principal desafio:

"Ser respeitada principalmente dependendo da área, setor em que trabalha. Muitas pessoas não levam a sério o seu negócio." (Empreendedora 14, 26 anos)

"Ser respeitada" (Empreendedora 11, 24 anos) 
Uma empreendedora citou o fato de, independente de gênero, o desafio estar ligado com o sucesso do empreendimento:

"O mesmo que qualquer um empreendedor de fazer o negócio crescer e ser bem sucedido." (Empreendedora 6, 48 anos) 


\section{Conclusões e recomendações para novos estudos}

\subsection{Conclusão}

Este trabalho teve como objetivo identificar e analisar a opinião das mulheres empreendedoras sobre suas dificuldades no processo empreendedor como também verificar se sofrem preconceito e de que tipo.

Para atingir esse objetivo foram realizadas pesquisas bibliográficas e de campo com a realização de entrevistas com mulheres empreendedoras no estado do Rio de Janeiro. A pesquisa bibliográfica apresentou conceitos como de empreendedorismo segundo o GEM (2010), empreendedor segundo Dornelas (2012), Filion (1999) e Schumpeter (1982, apud PEDROSO, MASSUKADO e MUSSI, 2009) e preconceito segundo o NEMGE (1996) e Queiroz (1995). Foi apresentado o papel da mulher na sociedade ao longo da história com abordagem da herança cultural de opressão a mulher, do movimento feminista e a conquista de direitos como a inserção da mulher no mercado de trabalho. Houve ainda a apresentação do surgimento e o crescimento do empreendedorismo, o perfil do empreendedor e o crescimento do empreendedorismo feminino bem como das motivações que fazem com que elas queiram abrir o negócio. Neste estudo também foram abordadas as dificuldades que as mulheres empreendedoras enfrentam ao longo do processo de empreender como, por exemplo, o preconceito de gênero e idade e as dificuldades relacionadas à família.

Com a pesquisa de campo, foi possível obter informações e fazer análises sobre o conteúdo abordado.

Entre as principais questões abordadas pelo estudo observou-se que $50 \%$ das mulheres sentem diferença de tratamento para pior por serem mulheres e donas do próprio negócio e 43,75\% destacam que sentem dificuldade de empreender por conta da idade. Essas informações permitem identificar que enquanto algumas mulheres jamais experimentaram qualquer tipo de discriminação, outras relataram discriminação de gênero e/ou de idade.

A maioria delas, $62,5 \%$, já sofreu preconceito de gênero e/ou idade no mundo dos negócios e isso segundo o relato dessas mulheres, ocorre com frequência quando se está em um ambiente ou área predominantemente masculina.

A maioria delas, $87,5 \%$, utilizou recursos próprios ou empréstimo familiar para abrir o negócio. Neste caso não foi possível identificar se houve preconceito de instituições 
financeiras para empréstimo de recurso, pois apenas uma que relatou ter feito empréstimo financeiro em banco e que pediu em nome de seu pai.

Houve também, com percentual reduzido, relatos de oposição familiar, porém explicados por instabilidade financeira do negócio por conta da recenticidade do mesmo e a família questionar o êxito do empreendimento, além do relato de oposição por conta do empreendimento estar inserido no terceiro setor.

Foi possível identificar a difícil conciliação entre o trabalho e a família visto que a maioria delas é casada e/ou com filho(s). Além também dessas empreendedoras serem donas de casa, pois a maioria não tem empregada e, consequentemente, cuidam das tarefas domésticas com níveis diferentes de ajuda do cônjuge e demais membros da família.

O maior desafio para essas mulheres, identificado em seus discursos, é a gestão do tempo devido à necessidade de conciliação de múltiplos papéis como esposa, mãe, empreendedora e dona de casa. Outro desafio presente no discurso foi a dificuldade para serem respeitadas.

Acredita-se que o objetivo deste trabalho foi alcançado, já que conseguiu identificar e analisar as dificuldades dessas mulheres empreendedoras no processo de empreender assim como verificar e identificar a existência de preconceitos e de que tipo.

\subsection{Sugestões e recomendações para novos estudos}

Sobre as recomendações para novos estudos, seria interessante realizá-lo com um maior número de empreendedoras, não somente da cidade do Rio de Janeiro e Cabo Frio mas de outras cidades do Rio de Janeiro para um resultado mais abrangente.

Um próximo estudo que aborde não só a opinião das mulheres empreendedoras como também a opinião da sociedade sobre o preconceito em relação a esse tipo de mulher.

Aplicar também um questionário utilizando uma escala de preconceito para medir o quão essa sociedade age de forma preconceituosa. 


\section{Referências Bibliográficas}

ALMEIDA, Joana Gomes de et al. Desemprego e Empreendedorismo: da ambiguidade da relação conceitual à eficácia das práticas de intervenção social. São Paulo, 2013. Disponível em: < http://www.revistas.usp.br/plural/article/view/69562/72134 >. Acesso em: 15 mar. 2016.

ALPERSTEDT, G. D.; FERREIRA, J. B.; SERAFIM, M. C. Empreendedorismo Feminino: Dificuldades Vivenciadas em Histórias de Vida. In: ENCONTRO DE ESTUDOS EM EMPREENDEDORISMO E GESTÃO DE PEQUENAS EMPRESAS (EGEPE), 7., 2014, Goiânia. Anais eletrônicos... Goiânia: EGEPE, 2014. Disponível em: < http://www.egepe.org.br/anais/tema07/266.pdf >. Acesso em: 19 set. 2015.

ANDREOLI, T. P; BORGES, W. A. Empreendedorismo Feminino: Uma Análise do Perfil Empreendedor e das Dificuldades Enfrentadas por Mulheres Detentoras de Um Pequeno Negócio. In: ENCONTRO PARANAENSE DOS ESTUDANTES DE ADMINISTRAÇÃO (EPEAD). 11., 2007, Paraná. Anais eletrônicos...: Paraná: EPEAD, 2007. Disponível em: < http://www.administradores.com.br/producao-academica/empreendedorismo-feminino-umaanalise-do-perfil-empreendedor-e-das-dificuldades-enfrentadas-por-mulheres-detentoras-deum-pequeno-negocio/410/ >. Acesso em: 15 mar. 2016.

ANUÁRIO DO TRABALHO NA MICRO E PEQUENA EMPRESA 2013. São Paulo, 2013. Disponível em:

http://www.sebrae.com.br/Sebrae/Portal\%20Sebrae/Anexos/Anuario\%20do\%20Trabalho\%2 0Na\%20Micro\%20e\%20Pequena\%20Empresa 2013.pdf >. Acesso em: 16 fev. 2016.

BAYLÃO, A. L. S.; SCHETTINO, E. M. O. A Inserção da Mulher no Mercado de Trabalho Brasileiro. In: SIMPÓSIO DE EXCELÊNCIA EM GESTÃO E TECNOLOGIA SEGeT. 6., 2014. Anais eletrônicos...: SEGeT, 2014. Disponível em: < http://www.aedb.br/seget/arquivos/artigos14/20320175.pdf >. Acesso em: 22 ago. 2015.

BOTELHO, Louise de Lira Roedel et al. Desafios gerenciais das mulheres empreendedoras: como exercer a liderança em espaços de identidade masculina? O caso da Alpha Tecnologia. Disponível em: http://www.researchgate.net/publication/38320124 Desafios gerenciais das mulheres emp 
reendedoras como exercer a liderana em espaos de identidade masculina $O$ caso da Alpha Tecnologia >. Acesso em: 5 set. 2015.

BUENO, A. M.; LEITE, M.L.G.; PILATTI, L. A. Empreendedorismo e comportamento empreendedor: como transformar gestores em profissionais empreendedores. In: ENCONTRO NACIONAL DE ENGENHARIA DE PRODUÇÃO ENEGEP, 14., 2004, Florianópolis. Anais eletrônicos... Florianópolis: ENEGEP, 2004. Disponível em: < http://www.pg.utfpr.edu.br/ppgep/Ebook/ARTIGOS/14.pdf >. Acesso em: 1 mar. 2016.

BUTTNER, H.; MOORE, D.'Women's organizational exodus to entrepreneurship: selreported motivations and correlates with sucess. Journal of Small Bussiness Management, Jan. p.34-47, 1997.

CASSOL, Neidi K. A Produção Científica na área de empreendedorismo feminino: análise dos estudos indexados na base de dados do Institute for Scientific Information (ISI). 2006. 136 f. Dissertação (Mestrado em Administração) - Universidade Regional de Blumenau, Blumenau. 2006.

CASSOL, Neidi Krewer; SILVEIRA, Amédia; HOELTGEBAUM, Marianne. Empreendedorismo feminino: análise da produção científica da base de dados do Institute for Scientific Information (ISI), 1997-2006. In: ENCONTRO DA ASSOCIAÇÃO NACIONAL DE PÓS-GRADUAÇÃO E PESQUISA EM ADMINISTRAÇÃO (ANPAD). 31., 2007, Rio de Janeiro. Anais eletrônicos... Rio de Janeiro: ANPAD, 2007. Disponível em: < http://www.anpad.org.br/admin/pdf/ESO-C1347.pdf >. Acesso em: 19 set. 2015.

COSTA, Ana A. A.; O movimento feminista no Brasil: Dinâmicas de uma intervenção política. Disponível em:

http://www.revistagenero.uff.br/index.php/revistagenero/article/viewFile/380/285 $>$. Acesso em: 6 mar. 2016.

CRAMER, Luciana et al. Representações femininas da ação empreendedora: uma análise da trajetória das mulheres no mundo dos negócios. Disponível em: < http://www.regepe.org.br/index.php/regepe/article/view/14/12 >. Acesso em: 15 mar. 2016.

DEL PRIORE, M. Ao sul do corpo: condição feminina, maternidade e mentalidades no Brasil Colônia. 2. ed. São Paulo: Ed. UNESP, 2009.

DENCKER, A. F. M. Métodos e técnicas de pesquisa em turismo. São Paulo: Futura, 2000. 
DORNELAS, José. Empreendedorismo: Transformando ideias em negócios. 4.ed. Rio de Janeiro: Elsevier, 2012.

DORNELAS, José. Empresas iniciantes com mulheres na diretoria têm mais chance de sobreviver. Economia UOL, São Paulo, out.2013. Disponível em: < http://economia.uol.com.br/ultimas-noticias/colunistas/jose-dornelas/2013/10/28/empresasiniciantes-com-mulheres-na-diretoria-tem-mais-chance-de-sobreviver.htm >. Acesso em: 19 set. 2015.

DRUCKER, P. F. Inovação e espírito empreendedor: prática e princípios. São Paulo: Pioneira, 1986.

FILION, L. J. Empreendedorismo: empreendedores e proprietários-gerentes de pequenos negócios. Revista de Administração. Abr/Jun. 1999, p. 5-28.

GEM - GLOBAL ENTREPRENEURSHIP MONITOR. Empreendedorismo no Brasil 2008. Curitiba: 2009 IBQP, Disponível em: < http://www.sebrae.com.br/Sebrae/Portal\%20Sebrae/Anexos/GEM-Brasil-2008.pdf >. Acesso em: 22 ago. 2015.

Empreendedorismo no Brasil - 2010. Curitiba: IBQP, 2010.

Disponível em:

http://www.sebrae.com.br/Sebrae/Portal\%20Sebrae/Anexos/livro gem 2010.pdf >. Acesso em: 23 ago. 2015.

Empreendedorismo no Brasil - 2015. Curitiba: IBQP, 2015.

Disponível em:

http://www.bibliotecas.sebrae.com.br/chronus/ARQUIVOS CHRONUS/bds/bds.nsf/c6de907f e0574c8ccb36328e24b2412e/\$File/5904.pdf >. Acesso em: 23 ago. 2015.

GOMES, A. F. O perfil empreendedor de mulheres que conduzem seu próprio negócio: Um estudo na cidade de Vitória da Conquista. Disponível em: < http://siaiap32.univali.br/seer/index.php/ra/article/view/1805/1433 >. Acesso em: 19 mar. 2016.

HISRICH, Robert D.; PETERS, Michael R. Empreendedorismo. 5.ed. Porto Alegre: Bookman, 2004.

IBGE. Censo Demográfico 2010. Disponível em: < http://wwwcenso2010.ibge.gov.br >. Acesso em: 15 fev. 2016. 
Demografia das empresas. Disponível em: < http://biblioteca.ibge.gov.br/visualizacao/livros/liv94575.pdf >. Acesso em: 9 mar. 2016.

. Mulher no Mercado de Trabalho: perguntas e respostas. Disponível em: < http://www.ibge.gov.br/home/estatistica/indicadores/trabalhoerendimento/pme nova/Mulher Mercado Trabalho Perg Resp 2012.pdf >. Acesso em: 29 ago. 2015.

. Projeções e estimativas da população do Brasil e das Unidades da

Federação 2015. Disponível em: < http://www.ibge.gov.br/apps/populacao/projecao/ >. Acesso em: 16 fev. 2016.

JONATHAN, Eva G. Empreendedorismo feminino no setor tecnológico brasileiro: dificuldades e tendências. In: EGEPE - ENCONTRO DE EMPREENDEDORISMO E GESTÃO DE PEQUENAS EMPRESAS. 3., 2003, Brasília. Anais eletrônicos...Brasíia, UEM/UEL/UnB, 2003, p. 41-53. Disponível em: < http://www.anegepe.org.br/edicoesanteriores/brasilia/[04].pdf $>$. Acesso em: 20 mar. 2016.

JONATHAN, Eva G. Mulheres empreendedoras: medos, conquistas e qualidade de vida. Psicologia em estudo, Maringá, V. 10, n. 3, 2005. Disponível em: < www.scielo.br/pdf/pe/v10n3/v10n3a04.pdf >. Acesso em: 15 mar. 2016.

KASSAI, Silvia. As Empresas de Pequeno Porte e a Contabilidade. São Paulo: 1996. Dissertação de Mestrado, FEA /USP. Disponível em: < http://www.scielo.br/pdf/cest/n15/n15a04 >. Acesso em: 15 mar. 2016.

LANGOWITS, Nan. O espírito empreendedor feminino. HSM Management, n. 43, p.64-68, março-abril 2004.

LEITE, C. L. P. Mulheres: Muito além do teto de vidro. São Paulo: Atlas, 1994.

LIMA, M. E. O. VALA, J. As novas formas de expressão do preconceito e do racismo. Disponível em: < http://www.scielo.br/scielo.php?script=sci arttext\&pid=S1413294X2004000300002 >. Acesso em: 18 mar. 2016.

MACHADO, H. V.; ST CYR, L.; MIONE. A.; ALVES, M. C. M. O processo de criação de empresas por mulheres. RAE-eletrônica. V. 2, n. 2, 2003. Disponível em: < http://www.scielo.br/pdf/raeel/v2n2/v2n2a07 >. Acesso em: 1 mar. 2016.

MACHADO, Hilka Pereira Vier. Empreendedoras e o preço do sucesso. REO - Revista de Estudos Organizacionais, Maringá, vol.1, n.2, p.75-88, jul./dez.2000. 
MARCONI, M. DE A.; LAKATOS, E. M. Técnicas de pesquisa: planejamento e execução de pesquisas, amostragens e técnicas de pesquisas, elaboração análise e interpretação de dados. $3^{\underline{a}}$ edição. São Paulo: Atlas, 1996.

MELO, Alexandre de. Os fatos históricos que marcaram as conquistas das mulheres. Revista Escola, mar.2013. Disponível em: < http://revistaescola.abril.com.br/fundamental2/fatos-historicos-conquistas-dia-da-mulher-735607.shtml\#ad-image-0 $>$. Acesso em: 22 ago. 2015.

MORAIS, Simone de. Mulheres empreendedoras no Brasil: fatores que as levam a empreender. Disponível em:

http://www.administradores.com.br/mobile/artigos/empreendedorismo/mulheresempreendedoras-no-brasil-fatores-que-as-levam-a-empreender/85498/ >. Acesso em: 15 mar. 2016.

MUSSAK, Eugênio. O entusiasmo do empreendedor. Vencer, São Paulo, n. 56, p.98, abr., 2004.

NAISBITT, J.; ABURDENE, P. Megatendências para as mulheres. Rio de Janeiro: Rosa dos Tempos, 1994.

PEDROSO, J. P. P.; MASSUKADO, M. S.; Mussi, F. B. A relação entre o jeitinho Brasileiro e o perfil empreendedor: possíveis interfaces no contexto da atividade empreendedora no Brasil. Disponível em: < http://www.scielo.br/scielo.php?script=sci arttext\&pid=S1678-69712009000400006 $>$. Acesso em: 19 mar. 2016.

PETERS, Tom. As mulheres reinam! HSM Management, n. 43, p.51-56, março-abril 2004.

POWELL, Gary N.; EDDLESTON, K. A. Lonking family-to-business enrichment and support to entrepreneurial sucess: do female and male entrepreneurs experience different outcomes? Journal of Business Venturing, v.28, n.2, 2013.

QUEIROZ, Renato da Silva. Não vi e não gostei: O fenômeno do preconceito. 3.ed. São Paulo: Moderna, 1995.

RODRIGUES, Júlia A. A construção histórica e cultural do gênero feminino e a valorização do trabalho da mulher. Disponível em: < http://www.ufpb.br/evento/lti/ocs/index.php/17redor/17redor/paper/download/241/108. $\quad>$. Acesso em: 3 mar. 2016. 
SEBRAE. Os donos de negócio no Brasil: análise por sexo (2003-2013). 2015. Disponível em:

http://www.bibliotecas.sebrae.com.br/chronus/ARQUIVOS CHRONUS/bds/bds.nsf/4b813ba 67e266bbdc48177dd04726c87/\$File/5452.pdf >. Acesso em: 22 fev. 2016.

Participação das Micro e Pequenas Empresas na Economia Brasileira.

2014.

Disponível

em:

http://www.sebrae.com.br/Sebrae/Portal\%20Sebrae/Estudos\%20e\%20Pesquisas/Participac ao\%20das\%20micro\%20e\%20pequenas\%20empresas.pdf >. Acesso em: 15 fev. 2016.

Perfil das mulheres empreendedoras da região metropolitana do Rio de Janeiro. 2012 Disponível em: < http://www.sebrae.com.br/Sebrae/Portal\%20Sebrae/UFs/RJ/Menu\%20Institucional/Sebrae EMP jun12 pf mulh emp.pdf $>$. Acesso em: 3 mar. 2016.

SILVA, Glauce Cerqueira Corrêa da et al. A mulher e sua posição na sociedade: da antiguidade aos dias atuais. Revista da sociedade brasileira de psicologia, dez.2005. Disponível em: < http://pepsic.bvsalud.org/scielo.php?script=sci arttext\&pid=S1516$\underline{08582005000200006}$ >. Acesso em: 22 ago. 2015.

SILVA, R. R. Mulheres empreendedoras: das dificuldades as conquistas no mundo dos negócios. Disponível em: < http://www.administradores.com.br/ resources/files/ modules/academics/academics 6632 01002281825025400.pdf >. Acesso em: 15 mar. 2016.

SOUZA, E. C. L. de. A Disseminação da Cultura Empreendedora e a Mudança na Relação Universidade-Empresa. In: Souza, Eda C. L. de (Org.). Empreendedorismo: competência essencial para pequenas e médias empresas. Brasília: ANPROTEC, 2001, p. 28 - 41.

THIRY-CHERQUES, Hermano R. Saturação em pesquisa qualitativa. 2009. Disponível em: < http://www.revistapmkt.com.br/Portals/9/Edicoes/Revista PMKT 003 02.pdf >. Acesso em: 3 nov. 2015.

TIMÓTEO, Carolina Q.; As transformações do movimento feminista no Brasil e sua relação com a América Latina. Disponível em: < http://www.uel.br/grupopesquisa/gepal/v7 carolina GVII.pdf >. Acesso em: 10 mar. 2016.

UNIVERSIDADE DE SÃO PAULO - NEMGE/CECAE (1996). Ensino e educação como igualdade de gênero na infância e na adolescência: guia prático para educadores e educadoras. São Paulo: NEMGE/CECAE. 
VERGARA, Sylvia C. Projetos e relatórios de pesquisa em administração. 3.ed. São Paulo: Atlas, 2000.

VILLAMARIN, Alberto J.G. Citações da Cultura Universal. AGE, 2002. 


\section{Apêndice 1}

Roteiro de entrevista:

Q1) Nome?

Q2) Idade?

O3) Estado civil?

Q4) Possui filhos?

Q5) Com quem mora?

Q6) Grau de escolaridade?

Q7) Em que?

Q8) Existe associação entre a formação e o empreendimento?

Q9) É uma empreendedora, ou seja, dona do próprio negócio?

Q10) Me fala sobre seu histórico empreendedor:

Q11) Levando em consideração a definição dada pelo SEBRAE (2015) que conceitua empreendedor por conta própria como uma pessoa que trabalha explorando o seu próprio empreendimento, sozinha ou com sócio, sem ter empregado e contando, ou não, com a ajuda de trabalhador não remunerado e empregador como uma pessoa que trabalha explorando o seu próprio empreendimento com, pelo menos, um empregado assalariado. Você é empreendedora por conta própria ou empregadora?

Q12) Se empregadora, quantos empregados (CLT) tem?

Q13) Quantos anos tinha quando decidiu empreender? Por que resolveu empreender?

Q14) Você é dona do seu negócio há quanto tempo?

Q15) Atua em qual setor?

Q16) Qual atividade?

Q17) Quem são seus principais clientes?

Q18) Quem são seus principais fornecedores?

Q19) Qual a carga diária que você dedica à vida de empreendedora? 
Q20) Qual seu rendimento médio mensal?

Q21) É seu trabalho único ou você possui outra fonte de renda?

Q22) Sua renda como empreendedora corresponde a quantos \% de sua renda total individual?

Q23) Quantas fontes de renda existem em sua casa?

Q24) Qual o percentual dos custos fixos mensais de sua família você arca?

Q25) Por qual ou quais razões você se tornou empreendedora?

Q26) Trabalhou antes em empresas com carteira assinada?

Q27) Por que saiu? Desligada? Por conta própria? Por quê?

Q28) Durante quanto tempo?

Q29) Qual o cargo mais alto ocupou?

Q30) Você percebe alguma diferença de tratamento por ser mulher e dona do próprio negócio?

Q31) Você sente falta de confiança depositada em você na sua própria empresa?

Q32) Você já sentiu ou sente dificuldade de empreender por conta da sua idade?

Q33) Você sente desafio em administrar seu negócio por ser mulher? Se sim, por quê?

Q34) Levando em consideração a afirmação do autor Queiroz (1995) que diz que o preconceito é um conceito prévio, formulado sem o cuidado de permitir que os fatos sejam investigados e possam contrariar nossos julgamentos ou opiniões. Você já sofreu preconceito no mundo dos negócios? Se sim, por quê?

Q35) Qual foi sua principal fonte de recurso para abrir o negócio?

Q36) Você percebeu dificuldade em obter o empréstimo?

Q37) Qual o percentual de tempo que você dedica a sua família e ao seu empreendimento?

Q38) Alguém da sua família já se opôs ao seu negócio? Se sim, quem e porque essa pessoa se opôs?

Q39) Você sente pressão familiar em casa por administrar seu negócio?

Q40) É difícil conciliar o trabalho com a família?

Q41) O cônjuge trabalha? Caso tenha cônjuge.

Q42) Com quem você deixa seus filhos quando vai trabalhar? Caso tenha filhos. 
Q43) Seu marido e seus filhos te apoiam como empreendedora? Caso tenha marido e filhos.

Q44) Você costuma ajudar nas tarefas domésticas quando chega do trabalho?

Q45) Seu marido e seus filhos ajudam nas tarefas de casa? Caso tenha marido e filhos.

Q46) Qual o maior desafio em ser uma mulher empreendedora?

Q47) Você pode citar e explicar uma situação em que tenha sido vítima de preconceito? Por que acha que o preconceito aconteceu?

Q48) Como você lida com o preconceito?

Q49) Em relação a quantidade de empreendedores você acha que

- Existe um equilíbrio entre a quantidade de homens e mulheres que empreendem

- Existem mais homens que mulheres empreendendo

- Existem mais mulheres que homens empreendendo.

Q50) Justifique a resposta acima, ou seja, por que você acha que isso acontece?

Q51) Qual foi sua principal alegria enquanto empreendedora?

Q52) Qual foi sua principal tristeza enquanto empreendedora? 